\title{
The Application of New Chiral Ferrocene Ligands in Asymmetric Transfer Hydrogenation of Ketones
}

\author{
Yuan-Zhao Mo, Quan-Jun Wang, Hui-Fang Nie, Qiao-Feng Wang* \\ School of Pharmacy, the Fourth Military Medical University, Xi'an, China \\ Email: * ${ }^{*} y t w q f @ f m m u . e d u . c n$
}

How to cite this paper: Mo, Y.-Z., Wang, Q.-J., Nie, H.-F. and Wang, Q.-F. (2018) The Application of New Chiral Ferrocene Ligands in Asymmetric Transfer Hydrogenation of Ketones. International Journal of Organic Chemistry, 8, 54-83.

https://doi.org/10.4236/ijoc.2018.81004

Received: December 6, 2017

Accepted: February 20, 2018

Published: February 23, 2018

Copyright ( 92018 by authors and Scientific Research Publishing Inc. This work is licensed under the Creative Commons Attribution International License (CC BY 4.0).

http://creativecommons.org/licenses/by/4.0/

\begin{abstract}
Four easily available ferrocenyl chiral ligands have been screened firstly for ruthenium (II)-catalyzed asymmetric transfer hydrogenation of acetophenone with $\mathrm{HCOOH} / \mathrm{Et}_{3} \mathrm{~N}$ azeotrope as the hydrogen source. A moderate chemical yield of 1-phenylethanol with $83 \%$ ee was obtained when $\left(R_{\mathrm{C}}, S_{\mathrm{Fc}}\right)$-1-(Diphenylphosphino)-2-[1-N-(3-methylpyridin-2-ylmethyl) ethyl] ferrocene $\left(\mathbf{L}_{1}\right)$ was used. Particularly, both ruthenium and iridium could coordinate with $\mathrm{L}_{1}$ to accomplish the asymmetric reduction of series of aromatic ketones separately. The desired products were achieved with up to $86 \%$ ee.
\end{abstract}

\section{Keywords}

Asymmetric Transfer Hydrogenation, Ferrocene, Ligand, Ketone

\section{Introduction}

Asymmetric transfer hydrogenation (ATH) often has been achieved by the help of the combination of transition metal and chiral ligands [1] [2] [3]. In the field, the exploration of new ligands or the new utilization of reported ones always attracted researcher's interest. Ferrocene-based chiral complexes generally played important roles in asymmetric reactions due to ferrocene's highly electron donating property as well as the unique structure [4] [5] [6] [7]. However, it should be noticed that most of the ATH catalyzed by chiral ferrocene derived catalysts used isopropanol as the hydrogen donor. Formic acid, as a more effective hydrogen donor for its irreversible kinetic enantioselectivity seldom collocated with ferrocenyl chiral ligands in ATH [8]-[13]. Furthermore, as far as transition metal in ATH was concerned, ruthenium and iridium could both be employed 
in ATH [14] [15] [16] [17]. Commonly, different transition metals' coordination with the same chiral ligand provides more possibility for more stereoinduction [18] [19] [20] [21] [22]. Therefore, chiral ferrocenyl derivatives' $\left(\mathbf{L}_{1}-\mathbf{L}_{4}\right.$, Figure 1) combination with the $\mathrm{HCOOH}$ hydrogen donor and its integration with two transition metals are both investigated. The results indicated that the ATH of aryl ketone could proceed smoothly at the presence of $\mathrm{L}_{1}-\mathrm{L}_{4}$ and formic acid. Among them, the reaction with $\mathrm{L}_{1}$-metal complex existed gave the best chemical yield and optical yield.

\section{Experimental}

\subsection{General}

All reactions involving air- or moisture-sensitive species were finished under $\mathrm{N}_{2}$ atmosphere. Solvents were dried by standard methods and freshly distilled before use if needed. All other chemicals were used as purchased. $\mathrm{L}_{1}-\mathrm{L}_{4}$ were prepared from $(R)$-Ugi's amine according the published reports [23]. NMR spectra were recorded on a Bruker AV-400 spectrometer with TMS as an internal reference. Chiral High Performance Liquid Chromatography (HPLC) analyses were completed with an Agilent 1200 series apparatus and Chiralpak OD-H and OJ-H columns. The configuration of the products was determined by comparison to the literature data.

\subsection{The General Procedure for $\mathrm{ATH}$ in $\mathrm{HCOOH} / \mathrm{Et}_{3} \mathrm{~N}$ (5:2)}

A Schlenk flask was charged with substrate $(1 \mathrm{mmol}),\left[\mathrm{Ru} \text { (p-cymene) } \mathrm{Cl}_{2}\right]_{2}$ $(0.0025 \mathrm{mmol})$ or $\left[\{\mathrm{IrCl}(\mathrm{COD})\}_{2}\right](0.0025 \mathrm{mmol})$, chiral ligand $(0.005 \mathrm{mmol})$ in $1 \mathrm{~mL}$ solvent and stirred at r.t. for 4 hours under $\mathrm{N}_{2}$ atmosphere. After that, 4 $\mathrm{mL} \mathrm{HCOOH} / \mathrm{Et}_{3} \mathrm{~N}$ azeotrope was injected by syringe. The mixture went on stirring at $-20^{\circ} \mathrm{C}$ for $48 \mathrm{~h}$ under $\mathrm{N}_{2}$. Subsequently, saturated $\mathrm{NaHCO}_{3}(5 \mathrm{~mL})$ and $\mathrm{H}_{2} \mathrm{O}(5 \mathrm{~mL})$ were added and the mixture was then extracted with EtOAc $(10 \mathrm{~mL})$ for three times and dried over by $\mathrm{Na}_{2} \mathrm{SO}_{4}$. Then after column chromatography, the pure product was got and identified by ${ }^{1} \mathrm{H}$ NMR. The analytical data
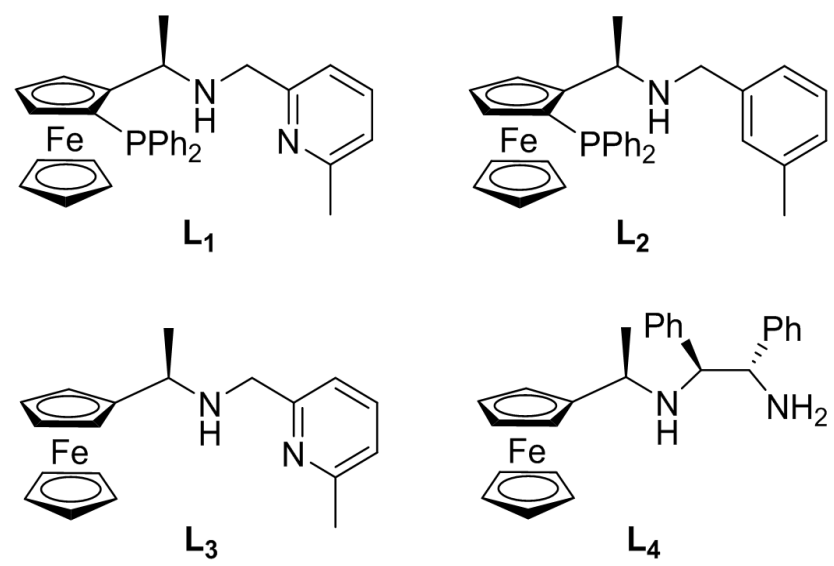

Figure 1. Ferrocene-based chiral ligands $\mathrm{L}_{1}-\mathrm{L}_{4}$. 
were given in supporting information.

\section{Results and Discussion}

$\mathrm{L}_{1}-\mathrm{L}_{4}$ 's synthesis could be accomplished according to our published report [23]. Once these ligands in hands, a preliminary study should be carrying out. Firstly, we have used $\mathrm{L}_{1}$ with $\mathrm{RuCl}_{2}$ ( $p$-cymene) as catalyst while acetophenone (1a) was substrate to optimize the reaction efficiency. Various solvents, different temperatures and the ratios of catalyst/substrate $(\mathrm{C} / \mathrm{S})$ were tested. The results were listed in Table 1.

The data in Table 1 showed that the solvent had influence on the experiment. For example, only trace conversion happened in $\mathrm{MeOH}, \mathrm{CH}_{2} \mathrm{Cl}_{2}$ and THF (Table 1, entry 1-3). Another three solvents (EtOAc, $t$-BuOMe, DMF) gave better chemical yields and better enantioselectivities. Among them, DMF provided the highest ee and chemical yield (Table 1, entry 1-6). So DMF was chosen as the optimized solvent for further experiments.

In DMF, ATH of 1a were conducted at different temperatures that ranged from r.t. to $-40^{\circ} \mathrm{C}$. Compared with r.t., $-20^{\circ} \mathrm{C}$ was proved to be a suitable reaction temperature with the improved ee value (Table 1, entry 6 vs. 7). However, when the temperature decreased to $-40^{\circ} \mathrm{C}$, only trace products could be observed (Table 1 , entry 8 ). So the rest of experiments were completed at $-20^{\circ} \mathrm{C}$.

Table 1 . The ATH reactions catalyzed by $\mathrm{L}_{1}$ with $\left[\mathrm{RuCl}_{2} \text { (p-cymene) }\right]_{2}$.<smiles>CC(=O)c1ccccc1</smiles>

$1 \mathrm{a}$

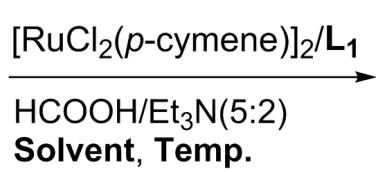

Solvent, Temp.

\begin{tabular}{cccccc}
\hline Entry & Solvent & $\mathrm{C} / \mathrm{S}$ & Temp. & ${\text { Yield }(\%)^{\mathrm{d}}}^{\mathrm{N}}$ & $\mathrm{Ee}(\%)^{\mathrm{e}}$ \\
\hline $1^{\mathrm{a}}$ & $\mathrm{MeOH}$ & $0.5 \%$ & r.t. & Trace & $\mathrm{ND}$ \\
$2^{\mathrm{a}}$ & $\mathrm{CH}_{2} \mathrm{Cl}_{2}$ & $0.5 \%$ & r.t. & Trace & $\mathrm{ND}$ \\
$3^{\mathrm{a}}$ & $\mathrm{THF}$ & $0.5 \%$ & r.t. & Trace & $\mathrm{ND}$ \\
$4^{\mathrm{a}}$ & $\mathrm{EtOAc}$ & $0.5 \%$ & r.t. & 27 & 45 \\
$5^{\mathrm{a}}$ & $t$-BuOMe & $0.5 \%$ & r.t. & 42 & 60 \\
$6^{\mathrm{a}}$ & $\mathrm{DMF}$ & $0.5 \%$ & r.t. & 74 & 79 \\
7 & $\mathrm{DMF}$ & $0.5 \%$ & $-20^{\circ} \mathrm{C}$ & 66 & 84 \\
8 & $\mathrm{DMF}$ & $0.5 \%$ & $-40^{\circ} \mathrm{C}$ & Trace & $\mathrm{ND}$ \\
$9^{\mathrm{b}}$ & $\mathrm{DMF}$ & $0.25 \%$ & $-20^{\circ} \mathrm{C}$ & 38 & 75 \\
$10^{\mathrm{c}}$ & $\mathrm{DMF}$ & $1 \%$ & $-20^{\circ} \mathrm{C}$ & 72 & 83 \\
\hline
\end{tabular}

aThe mixture of $1 \mathrm{mmol}$ of $1 \mathrm{a}, 0.0025 \mathrm{mmol}$ of $\left[\mathrm{RuCl}_{2}(p \text {-cymene) }]_{2}\right.$ and $0.005 \mathrm{mmol}$ of $\mathrm{L}_{1}$ in $4 \mathrm{~mL}$ $\mathrm{HCOOH} / \mathrm{Et}_{3} \mathrm{~N}(5: 2)$ azeotrope and $1 \mathrm{~mL}$ solvent at r.t. was stirred for $48 \mathrm{~h}$; ${ }^{\mathrm{b}} \mathrm{Cat}$. $(0.25 \mathrm{~mol} \%)$; ${ }^{\mathrm{c}} \mathrm{Cat}$. (1 $\mathrm{mol} \%)$; ${ }^{\mathrm{d}}$ Isolated yields after column chromatography; ${ }^{\mathrm{e}}$ The ee values was determined by chiral HPLC with Chiralpak OD-H column and the configuration was assigned by comparing the optical rotation with reported values [24] [25] [26] [27]. 
Additionally, the change of $\mathrm{C} / \mathrm{S}$ from $0.5 \%$ to $0.25 \%$ caused a lower chemical yield and lessened ee (Table 1, entry 9). But the bigger ratio did not mean the improved results. When the ratio was $1 \%$, the yield was raised slightly and the ee value was almost the same as that of $0.5 \% \mathrm{C} / \mathrm{S}$ (Table 1 , entry 7 vs. entry 10). Therefore, the $0.5 \%$ of $\mathrm{C} / \mathrm{S}$ was reasonable for next work.

Under the optimized conditions, the ligands structure effect on the ATH was also screened. The corresponding results were shown in Table 2 . $\mathrm{L}_{1}$ with $\mathrm{P}, \mathrm{N}, \mathrm{N}$ elements and planar chirality gave the best optical selectivity ( $84 \%$ ee) (Table 2 , entry 1 ). $\mathrm{L}_{2}$ 's result ( $81 \%$ ee) was a little worse than $\mathrm{L}_{1}$ 's (Table 2 , entry 2 ). It implied that $\mathrm{N}$ atom on pyridine unit of $\mathrm{L}_{1}$ had positive effect on the stereoinduction and the yield. The behaviors of $\mathrm{L}_{3}, \mathrm{~L}_{4}$ were both worse. $\mathrm{L}_{3}$ 's racemic result was not surprising for the reason that there was only one stereogenic center in $\mathrm{L}_{3}$ (Table 2 , entry 3 ). $\mathrm{L}_{4}$ gave $(S)$-products with $37 \%$ ee (Table 2 , entry 4 ). The configuration of moiety in $\mathrm{L}_{4}$ is also $(S, S)$. This indicated that the configuration of the product was controlled by the chiral diamine moiety in ligand structure. The chirality of Uig's amine had not apparent contribution to the stereocontrol. Altogether, the planer chiral elements and the $\mathrm{P}$ unit on the ferrocene ring were essential for a higher enantioselectivities. As far as the chemical yields were concerned, the four ligands' performance was almost similar. Lastly, $\mathrm{L}_{1}$ was choosed to be examined for various ketones' ATH.

As Table 3 summarized, for $\mathrm{L}_{1}-\mathrm{Ru}$ or $\mathrm{L}_{1}$-Ir catalyst, the reactions of acetophenone derivatives proceed smoothly. The ee values ranged from $66 \%$ to $86 \%$. First, the position of the ring substituents had influence on the enantioselectivity. Then it seems that electronic properties of the ring substituents had no effect on the results because 3-methoxyacetophenone or 3'-(trifluoromethyl) acetophenone almost obtained the paralleled stereoselectivity (Table 3, entry 4, 5). Furthermore, for halogen substituted substrates, with the increase of atomic number of halogen, the ees of the reaction had a little increase (Table 3, entry

Table 2. The screen of $\mathrm{L}_{1}-\mathrm{L}_{4}$ with $\left[\mathrm{RuCl}_{2} \text { (p-cymene) }\right]_{2}$ in the ATH.

\begin{tabular}{cccc}
\hline \\
Entry
\end{tabular}

${ }^{\mathrm{a}} 1 \mathrm{mmol}$ of $1 \mathrm{a}$ with $0.0025 \mathrm{mmol}$ of $\left[\mathrm{RuCl}_{2}(p \text {-cymene })\right]_{2}, 0.005 \mathrm{mmol}$ of ligand, $4 \mathrm{~mL} \mathrm{HCOOH} / \mathrm{Et}_{3} \mathrm{~N}(5: 2)$ and $1 \mathrm{~mL}$ DMF was stirred for $48 \mathrm{~h}$ at $-20^{\circ} \mathrm{C}$; ' Isolated yields after column chromatography; 'The ee and configuration of product were determined by chiral HPLC and according to literature [24] [25] [26] [27]. 
Table 3. The ATH of aromatic ketones catalyzed by $\mathrm{L}_{1}-\mathrm{Ru}$ or $\mathrm{L}_{1}$-Ir catalyst.
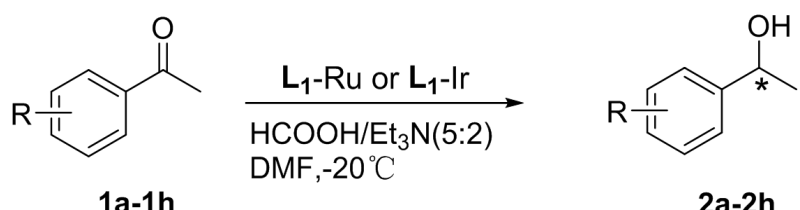

2a-2h

\begin{tabular}{ccccc}
\hline Entry & $\mathrm{R}$ & Product & Yield/ee $(\%)^{\mathrm{a}}$ & ${\text { Yield/ee }(\%)^{\mathrm{b}}}^{\mathrm{a}}$ \\
\hline $1^{\mathrm{c}}$ & $\mathrm{H}$ & $2 \mathrm{a}$ & $66 / 84(R)$ & $60 / 83(R)$ \\
$2^{\mathrm{c}}$ & $2-\mathrm{Br}$ & $2 \mathrm{~b}$ & $60 / 66(R)$ & $65 / 77(R)$ \\
$3^{\mathrm{c}}$ & $3-\mathrm{Br}$ & $2 \mathrm{c}$ & $63 / 76(R)$ & $65 / 82(R)$ \\
$4^{\mathrm{c}}$ & $3-\mathrm{CF}_{3}$ & $2 \mathrm{~d}$ & $57 / 79(R)$ & $62 / 85(R)$ \\
$5^{\mathrm{c}}$ & $3-\mathrm{OMe}$ & $2 \mathrm{e}$ & $60 / 80(R)$ & $68 / 81(R)$ \\
$6^{\mathrm{c}}$ & $4-\mathrm{F}$ & $2 \mathrm{f}$ & $55 / 67(R)$ & $60 / 70(R)$ \\
$7^{\mathrm{c}}$ & $4-\mathrm{Cl}$ & $2 \mathrm{~g}$ & $65 / 84(R)$ & $60 / 72(R)$ \\
$8^{\mathrm{c}}$ & $4-\mathrm{Br}$ & $2 \mathrm{~h}$ & $66 / 86(R)$ & $55 / 76(R)$ \\
\hline
\end{tabular}

${ }^{\mathrm{a}} 1 \mathrm{mmol}$ of 1 with $0.0025 \mathrm{mmol}$ of $\left[\mathrm{RuCl}_{2}(p \text {-cymene) }]_{2}, 0.005 \mathrm{mmol}\right.$ of $\mathrm{L}_{1}, 4 \mathrm{~mL} \mathrm{HCOOH} / \mathrm{Et}_{3} \mathrm{~N}(5: 2)$ and 1 $\mathrm{mL}$ DMF was stirred for $48 \mathrm{~h}$ at $-20^{\circ} \mathrm{C}$; ${ }^{\mathrm{b}} 1 \mathrm{mmol}$ of 1 with $0.0025 \mathrm{mmol}$ of $\left[\mathrm{IrCl}_{2}(\mathrm{COD})_{2}\right], 0.005 \mathrm{mmol}$ of $\mathrm{L}_{1}$,

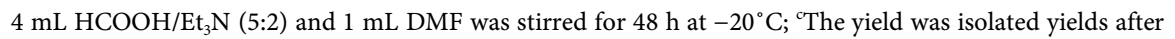
column chromatography. The ee and configuration of product were determined by chiral HPLC with Chiralpak OD-H or OJ-H. The absolute configuration was determined by comparison of the sign of optical rotation or retention time with literature data [24] [25] [26] [27].

6-8). All the chemical yields reached moderate (55\% - 68\%). In addition, almost no difference existed between the performance of Ru and Ir catalyst in the ATH of various substrates.

\section{Conclusion}

In conclusion, we have demonstrated four chiral ferrocene-based ligands' utilization in ATH of aromatic ketones. Herein, $\mathrm{HCOOH} / \mathrm{Et}_{3} \mathrm{~N}$ (5:2) system was firstly applied in this kind of reduction with chiral ferrocenyl ligands complexes existed. Both ruthenium and iridium could coordinate with $\mathrm{L}_{1}$ and could realize the reduction of acetophenone derivatives. Moderate to good enantiomeric excesses and medium isolated yields were achieved. Further studies of these ligands in other catalytic reactions are currently underway.

\section{Acknowledgments}

Financial support from the National Natural Science Foundation of China (NSFC, Nos. 21102175) and the Natural Science Foundation of Shaanxi Province, China (No.2016JM8070) are gratefully acknowledged.

\section{References}

[1] Wu, M., Cheng, T.Y., Ji, M., and Liu, G.H. (2015) Ru-Catalyzed Asymmetric Transfer Hydrogenation of $\alpha$-Trifluoromethylimines. The Journal of Organic Chemistry, 80, 3708-3713. http://doi.org/10.1021/acs.joc.5b00177 
[2] Seo, Y.J., Kim, J.A. and Lee, H.K. (2015) Stereoselective Synthesis of 4-Substituted Cyclic Sulfamidate-5-Phosphonates by Using Rh-Catalyzed, Asymmetric Transfer Hydrogenation with Accompanying Dynamic Kinetic Resolution. The Journal of Organic Chemistry, 80, 8887-8902. http://doi.org/10.1021/acs.joc.5b01434

[3] Lee, D.M., Kwak, S.H. and Lee, K.I. (2009) Highly Enantioselective Rh-Catalyzed Transfer Hydrogenation of $\alpha$-Functionalized Arylketones. Bulletin of the Korean Chemical Society, 30, 1317-1324. http://doi.org/10.5012/bkcs.2009.30.6.1317

[4] Dai, L.X., Tu, T., You, S.L., Deng, W.P. and Hou, X.L. (2003) Asymmetric Catalysis with Chiral Ferrocene Ligands. Accounts of Chemical Research, 36, 659-667. http://doi.org/10.1021/ar020153m

[5] Hellmuth, T., Rieckhoff, S., Weiss, M., Dorst, K., Frey, W. and Peters, R. (2014) Cooperative Bimetallic Asymmetric Catalysis: Comparison of a Planar Chiral Ruthenocene Bis-Palladacycle to the Corresponding Ferrocene. ACS Catalysis, 4, 1850-1858. http://doi.org/10.1021/cs500393x

[6] Zhou, Y., Zhu, F.L., Liu, Z.T., Zhou, X.M. and Hu, X.P. (2016) Chiral Ferrocenyl P,N-Ligands for Palladium-Catalyzed Asymmetric Formal [3 + 2] Cycloaddition of Propargylic Esters with $\beta$-Ketoesters: Access to Functionalized Chiral 2,3-Dihydrofurans. Organic Letters, 18, 2734-2737.

http://doi.org/10.1021/acs.orglett.6b01192

[7] Gao, D.W., Shi, Y.C., Gu, Q., Zhao, Z.L. and You, S.L. (2013) Enantioselective Synthesis of Planar Chiral Ferrocenes via Palladium-Catalyzed Direct Coupling with Arylboronic Acids. Journal of the American Chemical Society, 135, 86-89. http://doi.org/10.1021/ja311082u

[8] Isik, U., Aydemir, M., Meric, N., Durap, F., Kayan, C., Temel, H. and Baysal, A. (2013) Tunable Ferrocenyl-Phosphinite Ligands for the Ruthenium(II)-Catalyzed Asymmetric Transfer Hydrogenation of Ketones. Journal of Molecular Catalysis A: Chemical, 379, 225-233. https://doi.org/10.1016/j.molcata.2013.08.005

[9] Mejía, E., Aardoom, R. and Togni, A. (2012) Asymmetric Transfer Hydrogenation of Ketones Catalyzed by Rhenium Complexes with Chiral Ferrocenylphosphane Ligands. European Journal of Inorganic Chemistry, 2012, 5021-5032. https://doi.org/10.1002/ejic.201200693

[10] Baratta, W., Chelucci, G., Herdtweck, E., Magnolia, S., Siega, K. and Rigo, P. (2007) Highly Diastereoselective Formation of Ruthenium Complexes for Efficient Catalytic Asymmetric Transfer Hydrogenation. Angewandte Chemie International Edition, 46, 7651-7654. https://doi.org/10.1002/anie.200702278

[11] Bünyamin, A.K., Aydemir, M., Durap, F., Meriç, N., Elma, D. and Baysal, A. (2015) Highly Efficient Iridium Catalysts Based on $C_{2}$-Symmetric Ferrocenyl Phosphinite Ligands for Asymmetric Transfer Hydrogenations of Aromatic Ketones. Tetrahedron: Asymmetry, 26, 1307-1313. https://doi.org/10.1016/j.tetasy.2015.10.002

[12] Bünyamin, A.K., Aydemir, M., Durap, F., Meriç, N., Elma, D. and Baysal, A. (2015) The First Application of $C_{2}$-Symmetric Ferrocenyl Phosphinite Ligands for Rhodium-Catalyzed Asymmetric Transfer Hydrogenation of Various Ketones. Inorganica Chimica Acta, 438, 42-51. https://doi.org/10.1016/j.ica.2015.09.003

[13] Ikariya, T. and Blacker, A.J. (2007) Asymmetric Transfer Hydrogenation of Ketones with Bifunctional Transition Metal-Based Molecular Catalysts. Account. Chemical. Research, 40, 1300-1308. http://doi.org/10.1021/ar700134q

[14] Morris, D.M., McGeagh, M., De Peña, D. and Merola, J.S. (2014) Extending the Range of Pentasubstituted Cyclopentadienyl Compounds: The Synthesis of a Series 
of Tetramethyl(Alkyl or Aryl)Cyclopentadienes $\left(\mathrm{Cp}^{* \mathrm{R}}\right)$, Their Iridium Complexes and Their Catalytic Activity for Asymmetric Transfer Hydrogenation. Polyhedron, 84, 120-135. https://doi.org/10.1016/j.poly.2014.06.053

[15] Malacea, R., Poli, R. and Manoury, E. (2010) Asymmetric Hydrosilylation, Transfer Hydrogenation and Hydrogenation of Ketones Catalyzed by Iridium Complexes. Coordination Chemistry Reviews, 254, 729-752. https://doi.org/10.1016/j.ccr.2009.09.033

[16] Zerla, D., Facchett, G., Fusè, M., Pellizzoni, M., Castellano, C., Cesarotti, E., Gandolfi, R. and Rimoldi, I. (2014) 8-Amino-5,6,7,8-Tetrahydroquinolines as Ligands in Iridium(III) Catalysts for the Reduction of Aryl Ketones by Asymmetric Transfer Hydrogenation (ATH). Tetrahedron: Asymmetry, 25, 1031-1037. https://doi.org/10.1016/j.tetasy.2014.06.003

[17] Popoola, S.A., Jaseer, E.A., Al-Saadi, A.A., Polo, V., Casado, M.A. and Oro, L.A. (2015) Iridium Complexes as Catalysts in the Hydrogen Transfer of Isopropanol to Acetophenone: Ligand Effects and DFT Studies. Inorganica Chimica Acta, 436, 146-151. https://doi.org/10.1016/j.ica.2015.07.031

[18] Kenichi, K., Kota, T., Hidehiro, U., Shibata, Y. and Tanaka, K. (2016) Rhodium-Catalyzed Atroposelective $[2+2+2]$ Cycloaddition of Ortho-Substituted Phenyl Diynes with Nitriles: Effect of Ortho Substituents on Regio- and Enantioselectivity. Organic Letters, 18, 2170-2173. http://doi.org/10.1021/acs.orglett.6b0079

[19] Liang, T., Zhang, W.D. and Michael, J.K. (2015) Iridium-Catalyzed C-C Coupling of a Simple Propargyl Ether with Primary Alcohols: Enantioselective Homoaldol Addition via Redox-Triggered (Z)-Siloxyallylation. Journal of the American Chemical Society, 137, 16024-16027. http://doi.org/10.1021/jacs.5b12131

[20] Meng, J.J., Lv, M.G. and Zhang, X.M. (2015) Highly Enantioselective Hydrogenation of o-Alkoxy Tetrasubstituted Enamides Catalyzed by a $\mathrm{Rh} /(R, S)$-JosiPhos Catalyst. Organic Letters, 17, 1842-1845. http://doi.org/10.1021/acs.orglett.5b00401

[21] Kobayashi, K., Yamamoto, Y. and Miyaura, N. (2011) Pd/Josiphos-Catalyzed Enantioselective $\alpha$-Arylation of Silyl Ketene Acetals and Mechanistic Studies on Transmetalation and Enantioselection. Organometallics, 30, 6323-6327.

http://doi.org/10.1021/om200945q

[22] Kevin, G.M.K., Diane, N.L. and Dong, V.M. (2014) Rh(I)-Catalyzed Intermolecular Hydroacylation: Enantioselective Cross-Coupling of Aldehydes and Ketoamides. Journal of the American Chemical Society, 136, 9471-9476.

http://doi.org/10.1021/ja504296x

[23] Mo, Y.Z., Nie, H.F., Lei, Y., Zhang, D.X., Li, X.Y., Zhang, S.Y. and Wang Q.F. (2016) Asymmetric Transfer Hydrogenation of $\gamma$-Aryl $\alpha, \gamma$-Dioxo-Butyric Acid Esters. RSC Advances, 6, 33126-33131. http://doi.org/10.1039/C6RA02500E

[24] Zoabi, A., Omar, S. and Abu-Reziq, R. (2015) Chiral Ruthenium Catalyst Immobilized within Magnetically Retrievable Mesoporous Silica Microcapsules for Aqueous Asymmetric Transfer Hydrogenations. European Journal of Inorganic Chemistry, 12, 2101-2109. http://doi.org/10.1002/ejic.201403212

[25] Han, M.L., Hub, X.P., Huang, J.D., Chen, L.G. and Zheng, Z. (2011) New Chiral Amino Alcohol Ligands Derived from 1-Phenylethylamine for Efficient Ru-Catalyzed Asymmetric Transfer Hydrogenation. Tetrahedron: Asymmetry, 22, 222-225. https://doi.org/10.1016/j.tetasy.2011.01.017

[26] Xie, J.H., Liu, X.Y., Xie, J.B., Wang, L.X. and Zhou, Q.L. (2011) An Additional Coordination Group Leads to Extremely Efficient Chiral Iridium Catalysts for 
Asymmetric Hydrogenation of Ketones. Angewandte Chemie International Edition, 50, 7329-7332. https://doi.org/10.1002/anie.201102710

[27] Chen, Y.C., Wu, T.F., Deng, J.G., Liu, H., Cui, X., Zhu, J., Jiang, Y.Z., Michael, C.K.C. and Albert, S.C.C. (2002) Multiple Dendritic Catalysts for Asymmetric Transfer Hydrogenation. The Journal of Organic Chemistry, 67, 5301-5306. http://doi.org/10.1021/jo0257795 


\section{Supplementary Materials}

1. Copies of the HPLC spectra of the catalysis products 2 [catalysts were ferrocene-based chiral ligands with Ru-complex]

\section{1) Table 1}

\section{1-Phenylethanol (2a)}

$27 \%$ yield, $45 \%$ ee in EtOAc. $42 \%$ yield, $60 \%$ ee in $t$-BuOMe. $74 \%$ yield, $79 \%$ ee in DMF at r.t. $66 \%$ yield, $84 \%$ ee in DMF at $-20^{\circ} \mathrm{C}$. $38 \%$ yield, $75 \%$ ee in DMF at $-20^{\circ} \mathrm{C}$ with $\mathrm{C} / \mathrm{S}=0.25 \%, 72 \%$ yield, $84 \%$ ee in DMF at $-20^{\circ} \mathrm{C}$ with $\mathrm{C} / \mathrm{S}=1 \%$ for $48 \mathrm{~h}$ (ligand is $\mathrm{L}_{1}$ ), determined by HPLC analysis (Chiralcel OD-H column, Hexane/i-PrOH $=95 / 5$, Flow rate: $1 \mathrm{~mL} / \mathrm{min}$, UV detection at $215 \mathrm{~nm}$ ).
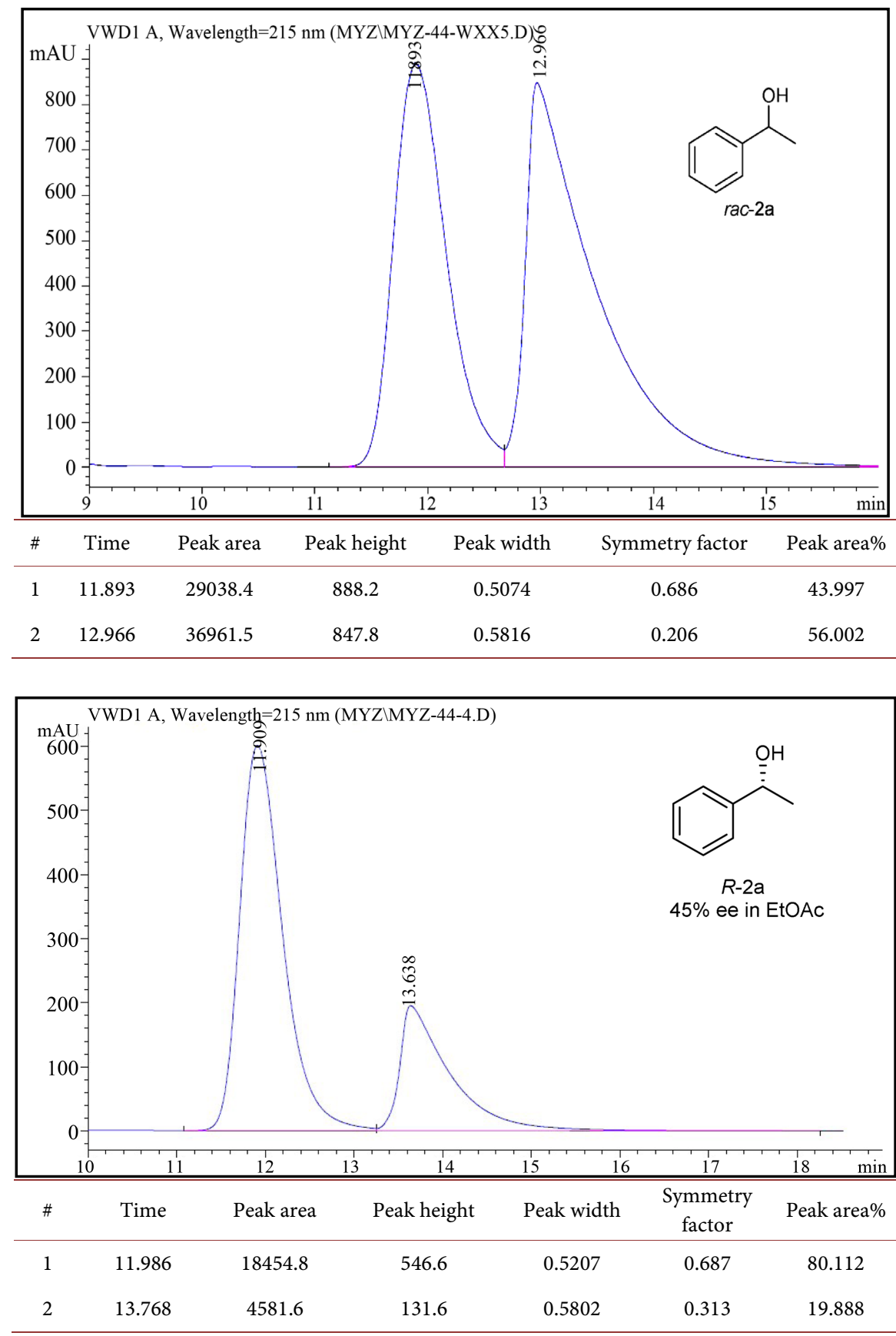

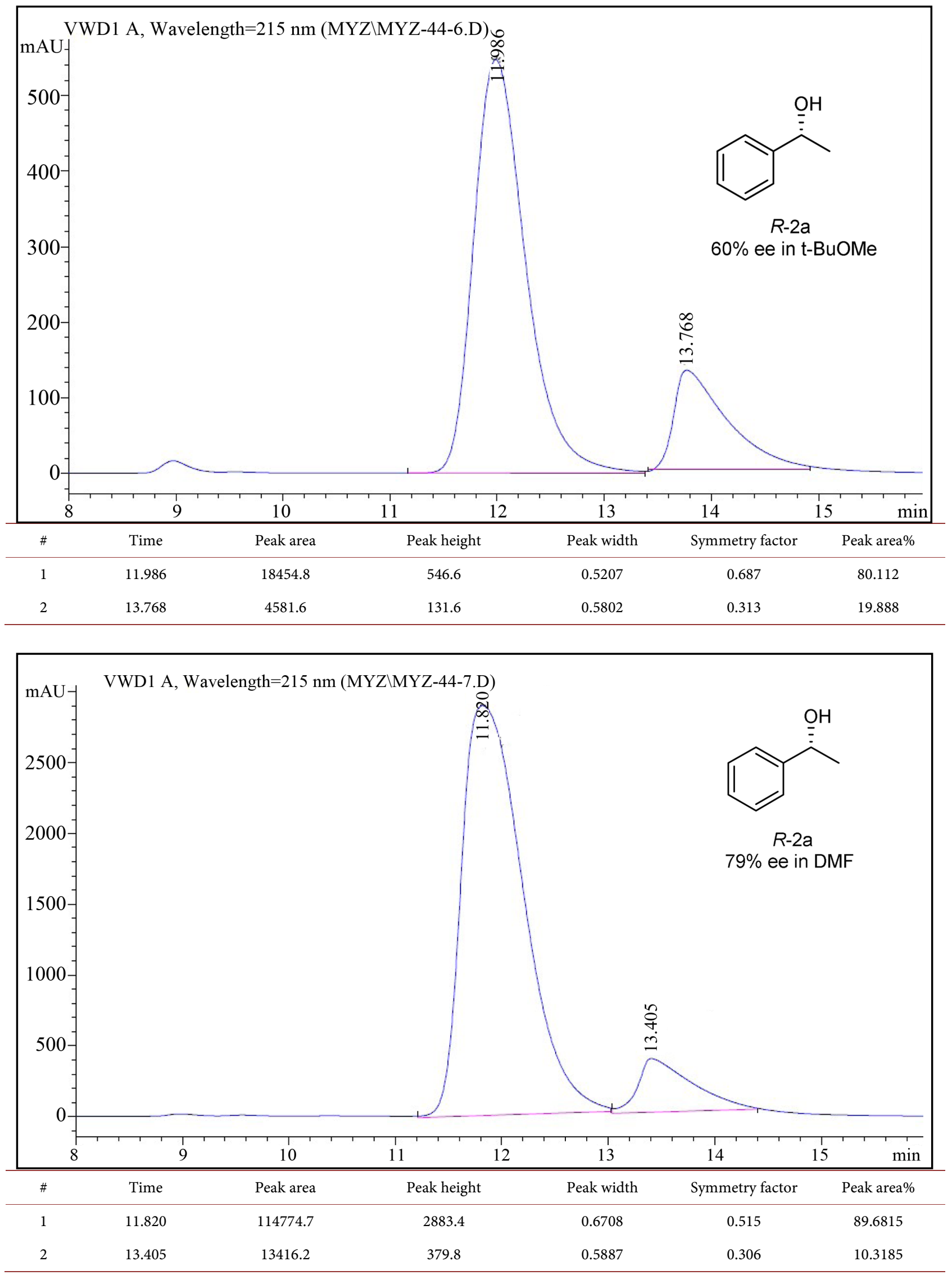

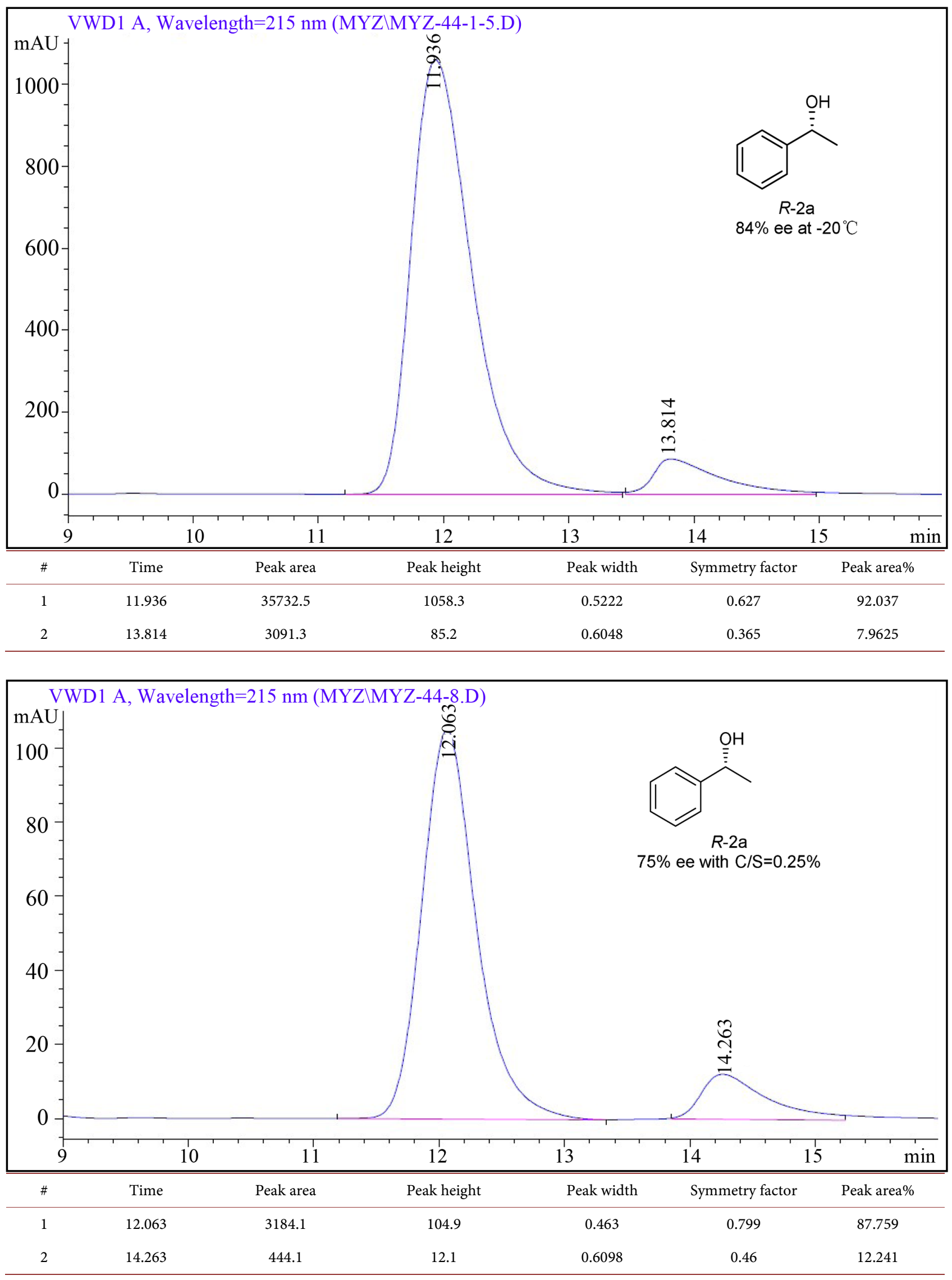


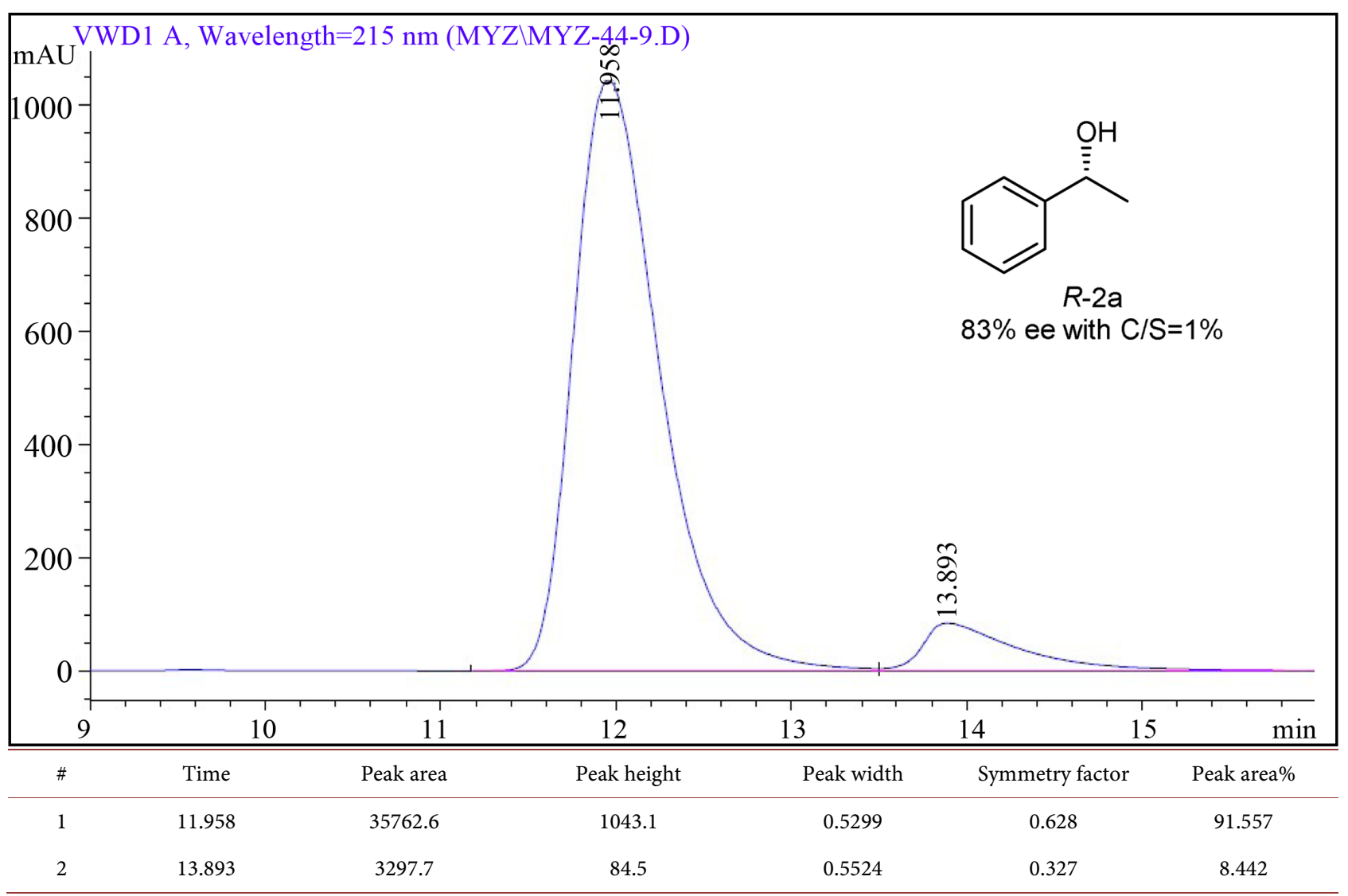

\section{2) Table 2}

$55 \%$ yield, $81 \%$ ee by L2 determined by HPLC analysis (Chiralcel OJ-H column, Hexane/i-PrOH = 90/10, Flow rate: $1 \mathrm{~mL} / \mathrm{min}$, UV detection at $215 \mathrm{~nm}$ ). $65 \%$ yield, racemic by L3. 50\% yield, $37 \%$ ee by L4 determined by HPLC analysis (Chiralcel OD-H column, Hexane/i-PrOH = 95/5, Flow rate: $1 \mathrm{~mL} / \mathrm{min}$, UV detection at $215 \mathrm{~nm}$ ).

3) Table 3

a) 1-(2-bromophenyl)ethanol (2b)

$60 \%$ yield, $66 \%$ ee determined by HPLC analysis (Chiralcel OJ-H column, Hexane $/ \mathrm{i}-\mathrm{PrOH}=95 / 5$, Flow rate: $1 \mathrm{~mL} / \mathrm{min}$, UV detection at $215 \mathrm{~nm}$ ).

\section{b) 1-(3-bromophenyl)ethanol (2c)}

$63 \%$ yield, $76 \%$ ee determined by HPLC analysis (Chiralcel OD-H column, Hexane/i-PrOH=98/2, Flow rate: $1 \mathrm{~mL} / \mathrm{min}$, UV detection at $215 \mathrm{~nm}$ ).

c) 1-(3-(trifluoromethyl)phenyl)ethanol (2d)

57\% yield, $79 \%$ ee determined by HPLC analysis (Chiralcel OD-H column, Hexane $/ \mathrm{i}-\mathrm{PrOH}=98 / 2$, Flow rate: $1 \mathrm{~mL} / \mathrm{min}$, UV detection at $215 \mathrm{~nm}$ ).

d) 1-(3-methoxyphenyl)ethanol (2e)

$60 \%$ yield, $80 \%$ ee determined by HPLC analysis (Chiralcel OD-H column, Hexane $/ \mathrm{i}-\mathrm{PrOH}=95 / 5$, Flow rate: $1 \mathrm{~mL} / \mathrm{min}$, UV detection at $215 \mathrm{~nm}$ ).

e) 1-(4-fluorophenyl)ethanol (2f)

$55 \%$ yield, $67 \%$ ee determined by HPLC analysis (Chiralcel OJ-H column, Hexane $/ \mathrm{i}-\mathrm{PrOH}=95 / 5$, Flow rate: $1 \mathrm{~mL} / \mathrm{min}, \mathrm{UV}$ detection at $215 \mathrm{~nm}$ ). 


\section{f) 1-(4-chlorophenyl)ethanol (2g)}

$65 \%$ yield, $84 \%$ ee determined by HPLC analysis (Chiralcel OJ-H column, Hexane $/ \mathrm{i}-\mathrm{PrOH}=95 / 5$, Flow rate: $1 \mathrm{~mL} / \mathrm{min}$, UV detection at $215 \mathrm{~nm}$ ).

\section{g) 1-(4-bromophenyl)ethanol (2h)}

$66 \%$ yield, $86 \%$ ee determined by HPLC analysis (Chiralcel OJ-H column, Hexane/i-PrOH $=95 / 5$, Flow rate: $1 \mathrm{~mL} / \mathrm{min}$, UV detection at $215 \mathrm{~nm}$ ).

2. Copies of the HPLC spectra of the catalysis products 2 [catalysts were ferrocene-based chiral ligands with Ir-complex]
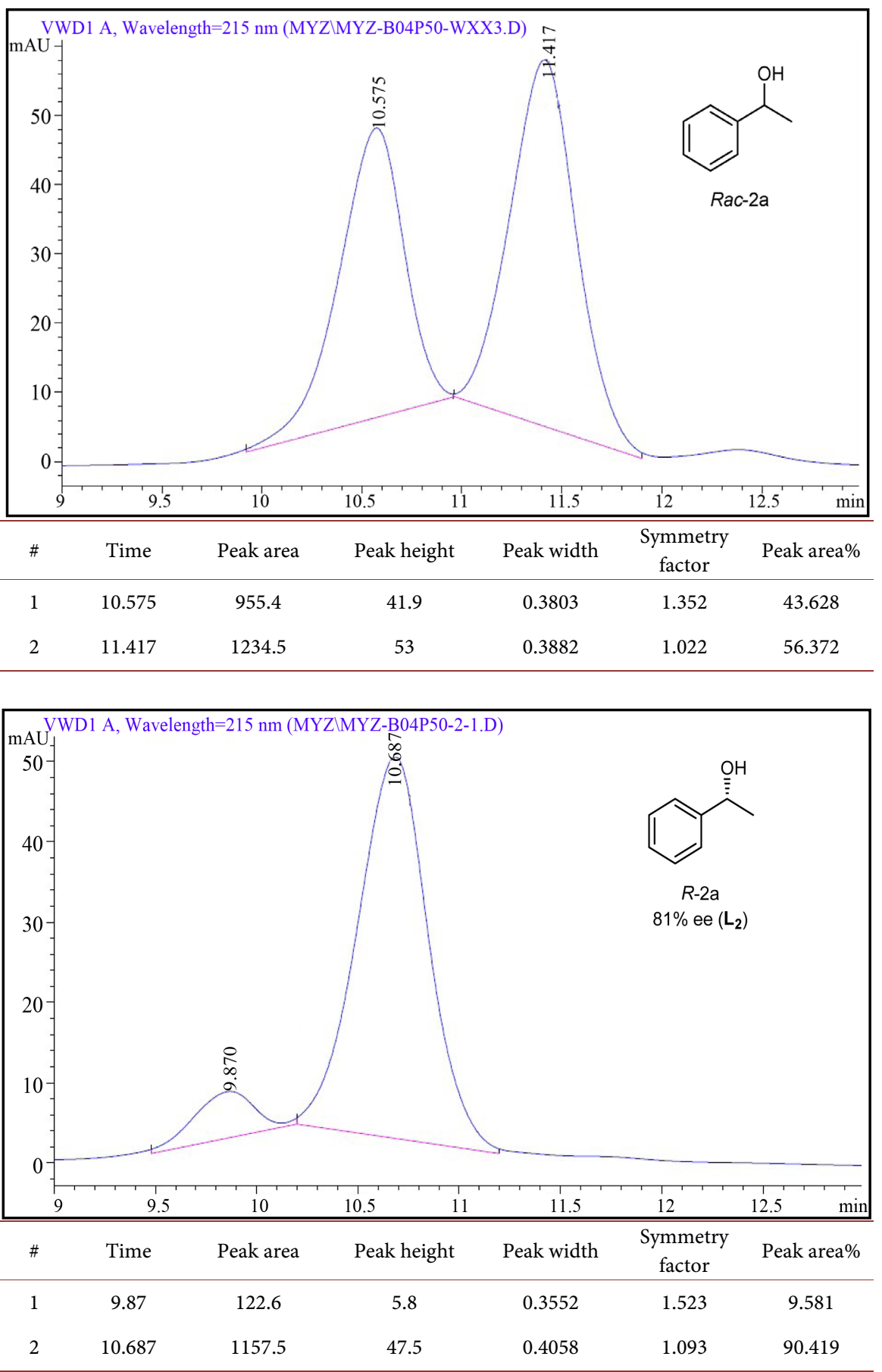

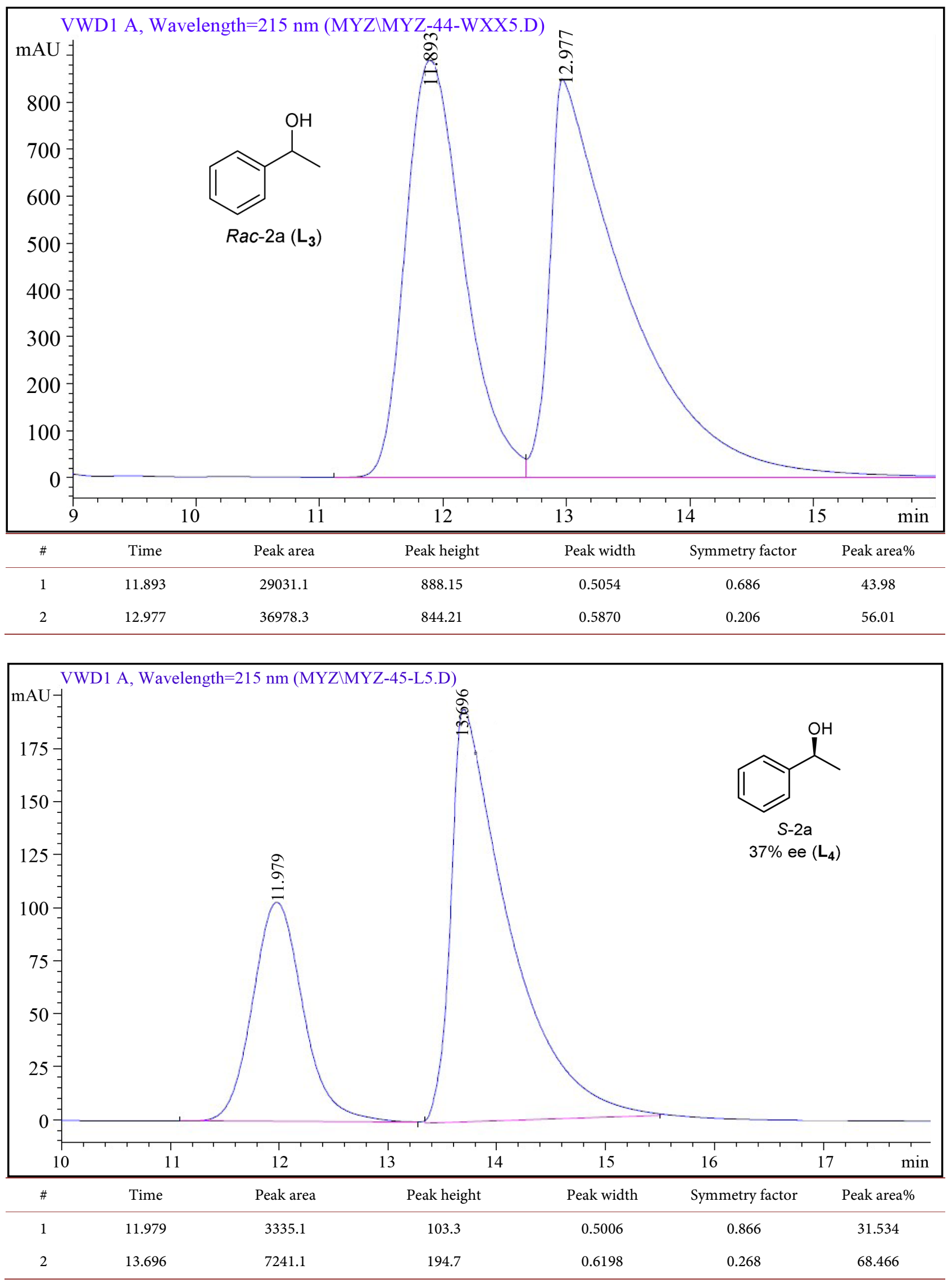


\section{Table 3}

\section{1) 1-Phenylethanol (2a)}

$60 \%$ yield, $83 \%$ ee determined by HPLC analysis (Chiralcel OJ-H column, Hexane/i-PrOH $=90 / 10$, Flow rate: $1 \mathrm{~mL} / \mathrm{min}$, UV detection at $215 \mathrm{~nm}$ )

\section{2) 1-(2-bromophenyl)ethanol (2b)}

$65 \%$ yield, $77 \%$ ee determined by HPLC analysis (Chiralcel OJ-H column, Hexane $/ \mathrm{i}-\mathrm{PrOH}=95 / 5$, Flow rate: $1 \mathrm{~mL} / \mathrm{min}$, UV detection at $215 \mathrm{~nm}$ ).

\section{3) 1-(3-bromophenyl)ethanol 2c)}

$65 \%$ yield, $82 \%$ ee determined by HPLC analysis (Chiralcel OJ-H column, Hexane/i-PrOH $=99 / 1$, Flow rate: $1 \mathrm{~mL} / \mathrm{min}$, UV detection at $215 \mathrm{~nm}$ ).

\section{4) 1-(3-(trifluoromethyl)phenyl)ethanol (2d)}

$62 \%$ yield, $85 \%$ ee determined by HPLC analysis (Chiralcel OJ-H column, Hexane $/ \mathrm{i}-\mathrm{PrOH}=99 / 1$, Flow rate: $1 \mathrm{~mL} / \mathrm{min}$, UV detection at $215 \mathrm{~nm}$ ).

\section{5) 1-(3-methoxyphenyl)ethanol (2e)}

$68 \%$ yield, $81 \%$ ee determined by HPLC analysis (Chiralcel OJ-H column, Hexane $/ \mathrm{i}-\mathrm{PrOH}=98 / 2$, Flow rate: $1 \mathrm{~mL} / \mathrm{min}$, UV detection at $215 \mathrm{~nm}$ ).

6) 1-(4-fluorophenyl)ethanol (2f)

$60 \%$ yield, $70 \%$ ee determined by HPLC analysis (Chiralcel OJ-H column, Hexane/i-PrOH $=99 / 1$, Flow rate: $1 \mathrm{~mL} / \mathrm{min}$, UV detection at $215 \mathrm{~nm}$ ).

\section{7) 1-(4-chlorophenyl)ethanol (2g)}

$60 \%$ yield, $72 \%$ ee determined by HPLC analysis (Chiralcel OJ-H column, Hexane/i-PrOH $=99 / 1$, Flow rate: $1 \mathrm{~mL} / \mathrm{min}$, UV detection at $215 \mathrm{~nm}$ ).

\section{8) 1-(4-bromophenyl)ethanol (2h)}

$55 \%$ yield, $76 \%$ ee determined by HPLC analysis (Chiralcel OJ-H column, Hexane/i-PrOH=98/2, Flow rate: $1 \mathrm{~mL} / \mathrm{min}$, UV detection at $215 \mathrm{~nm}$ ).

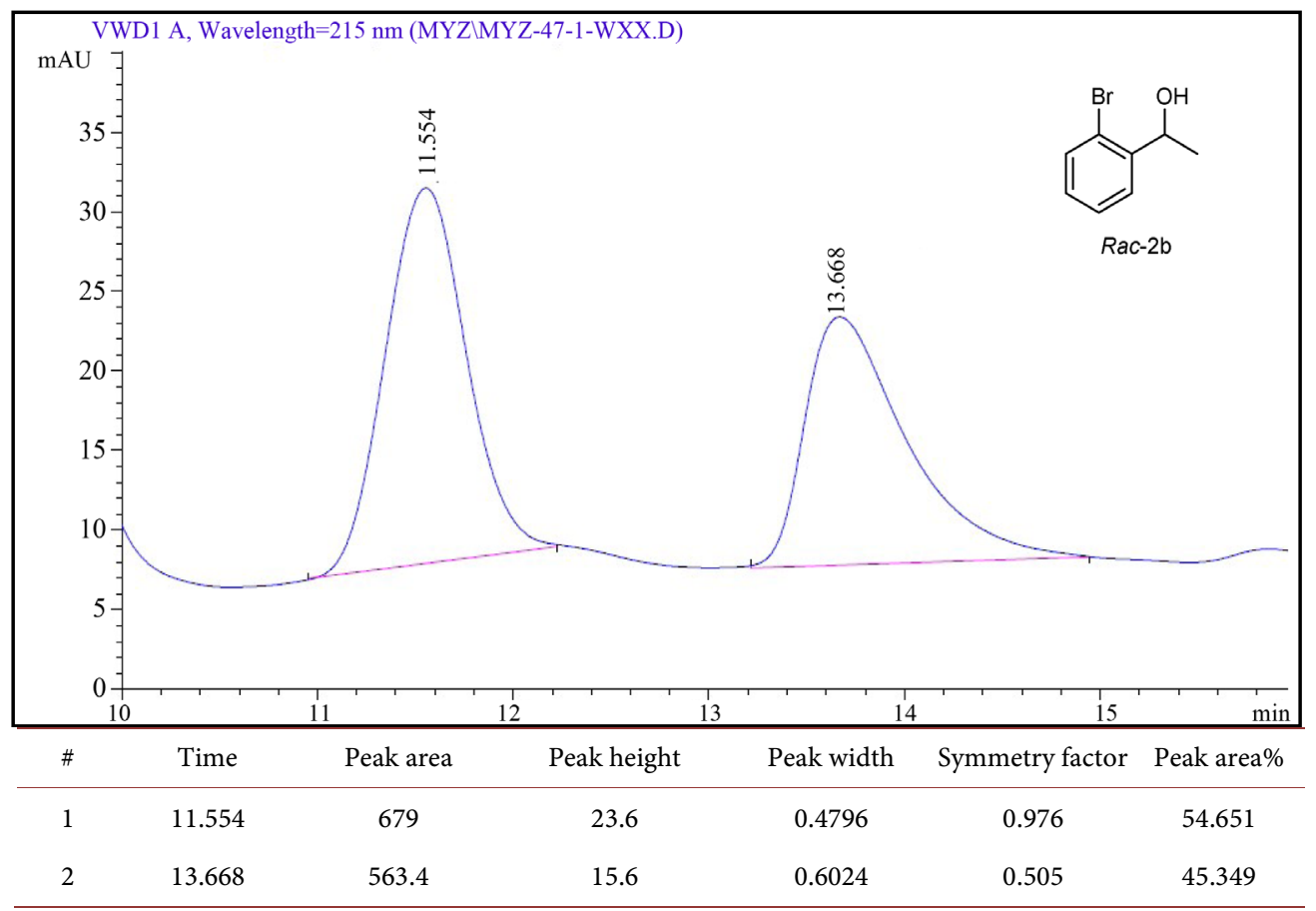



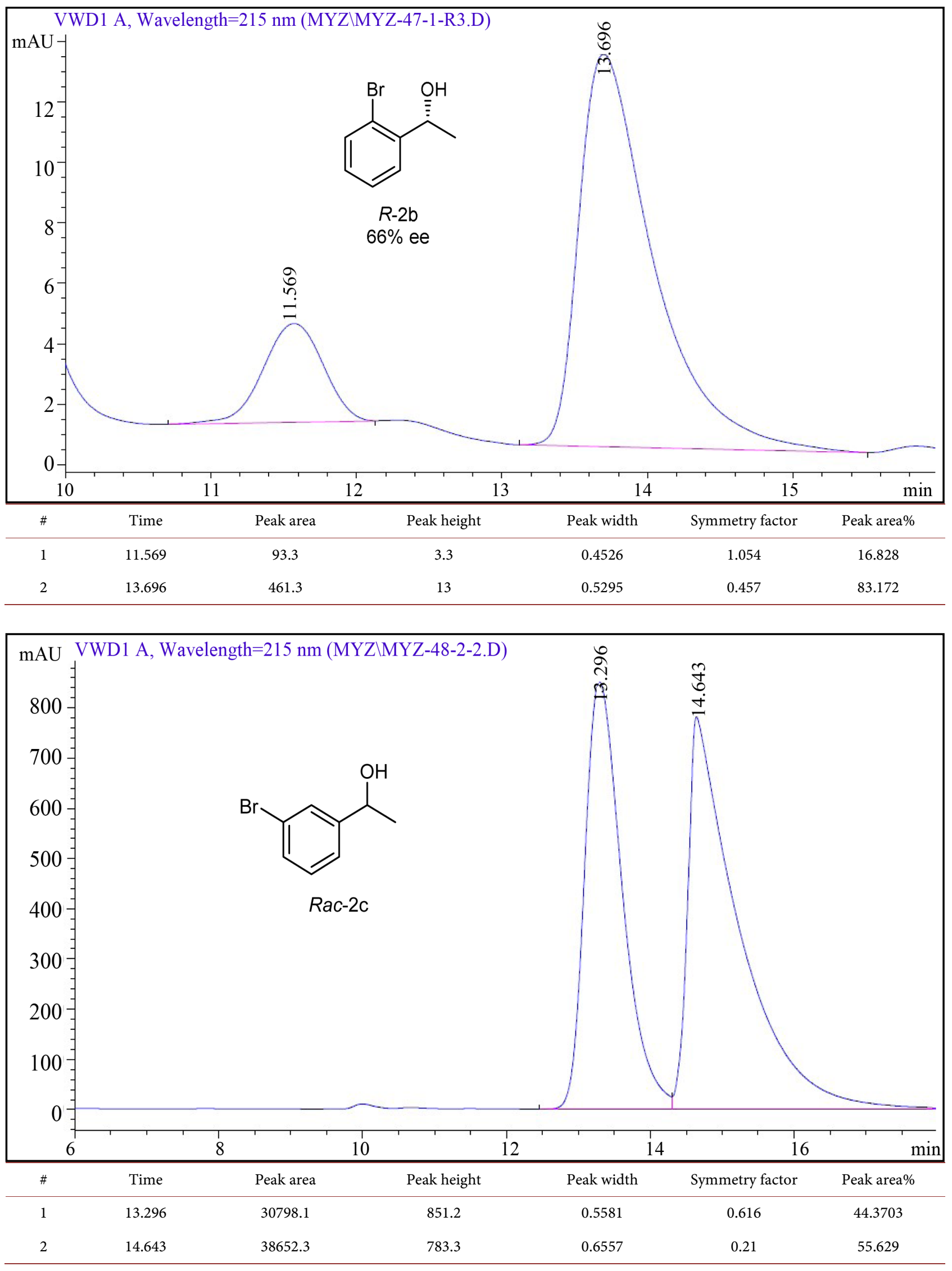

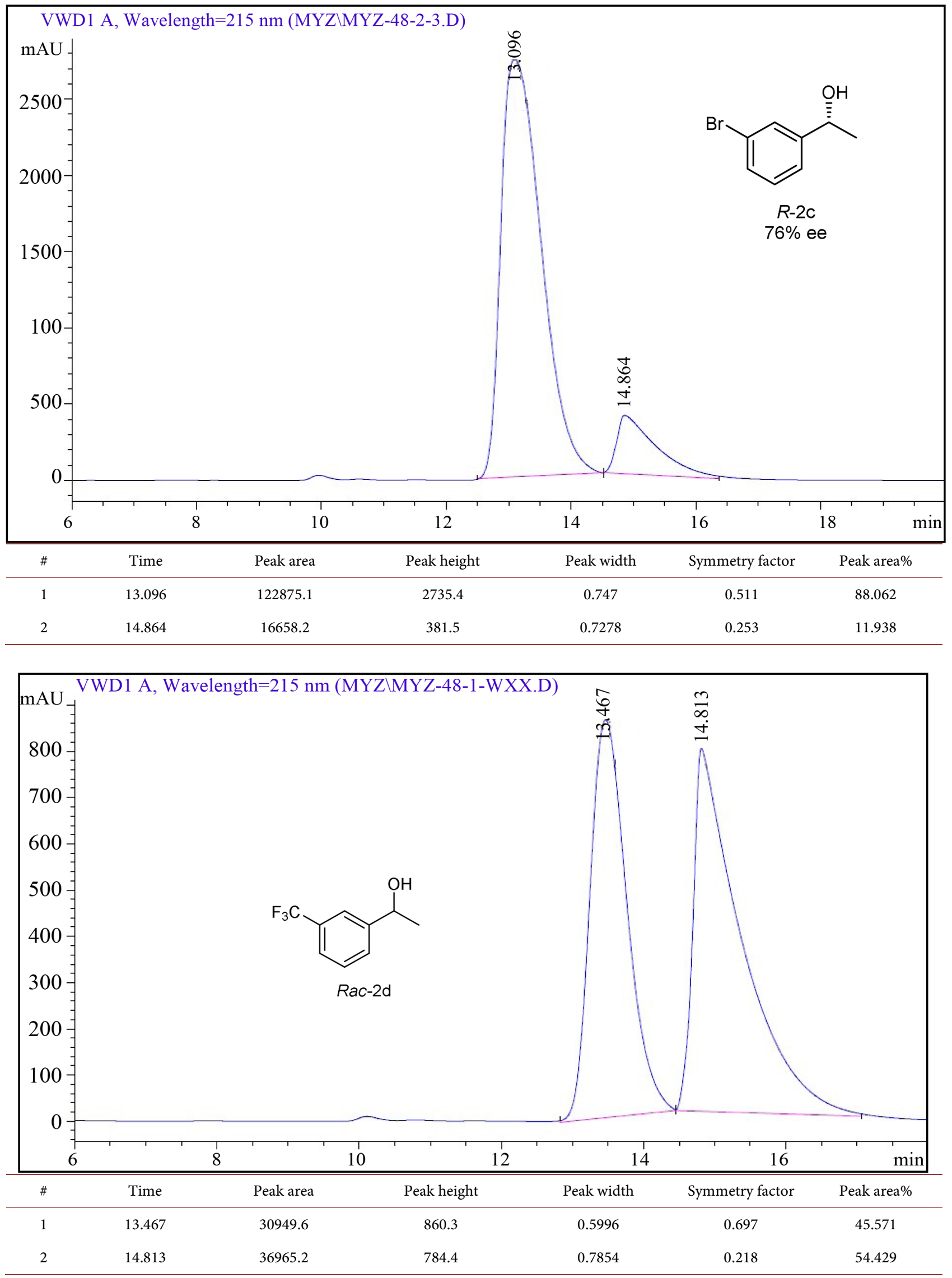

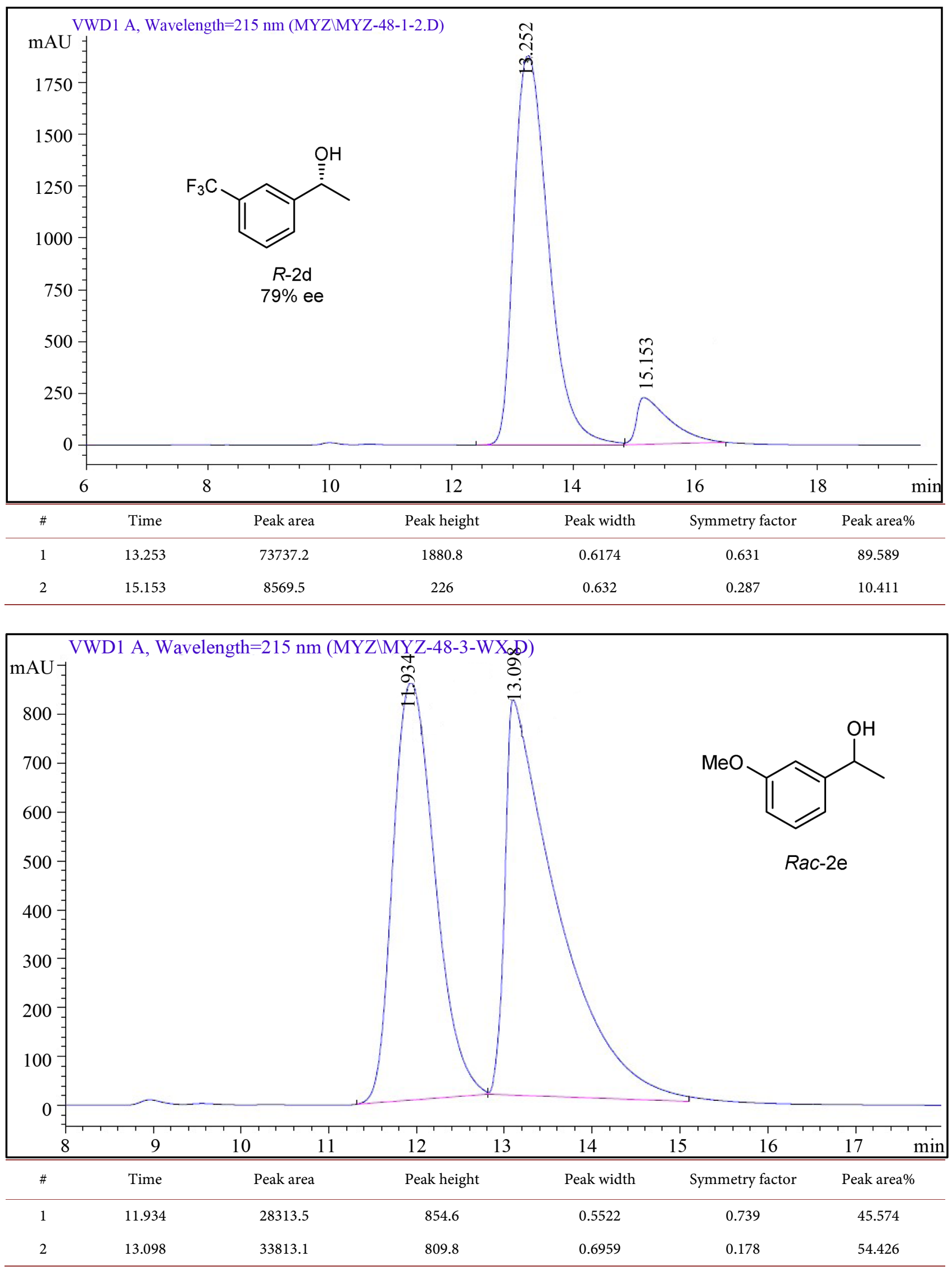

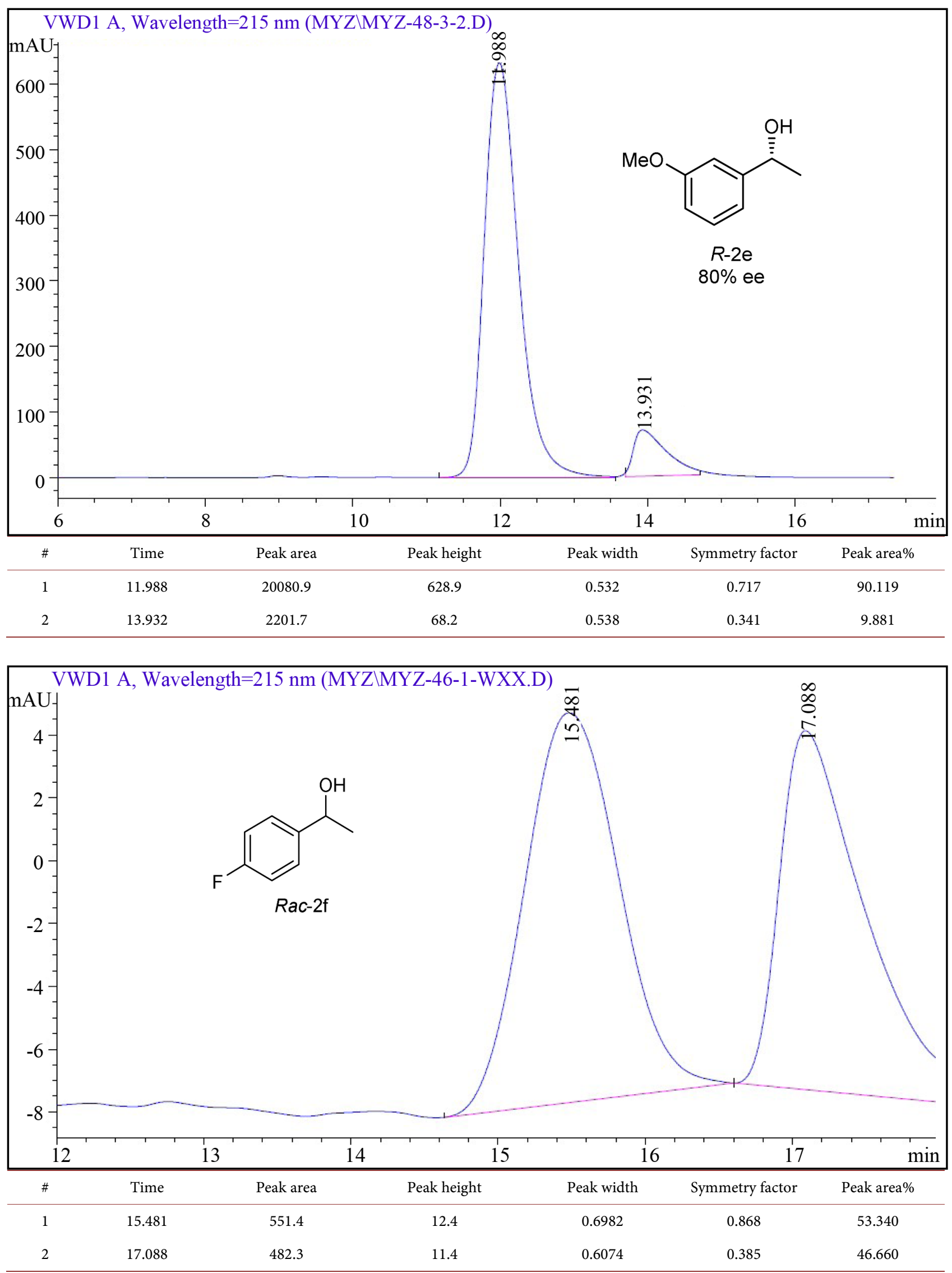

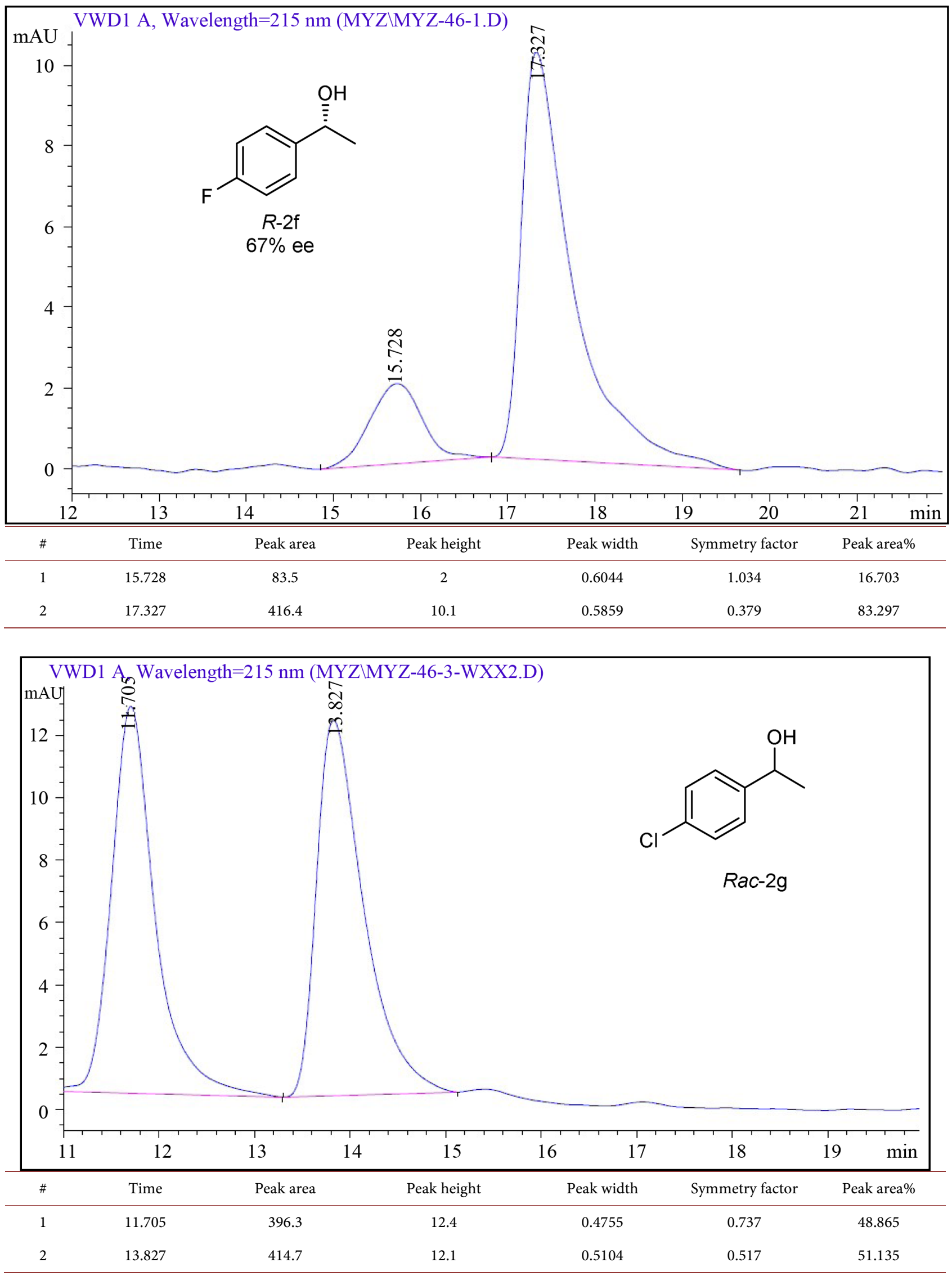

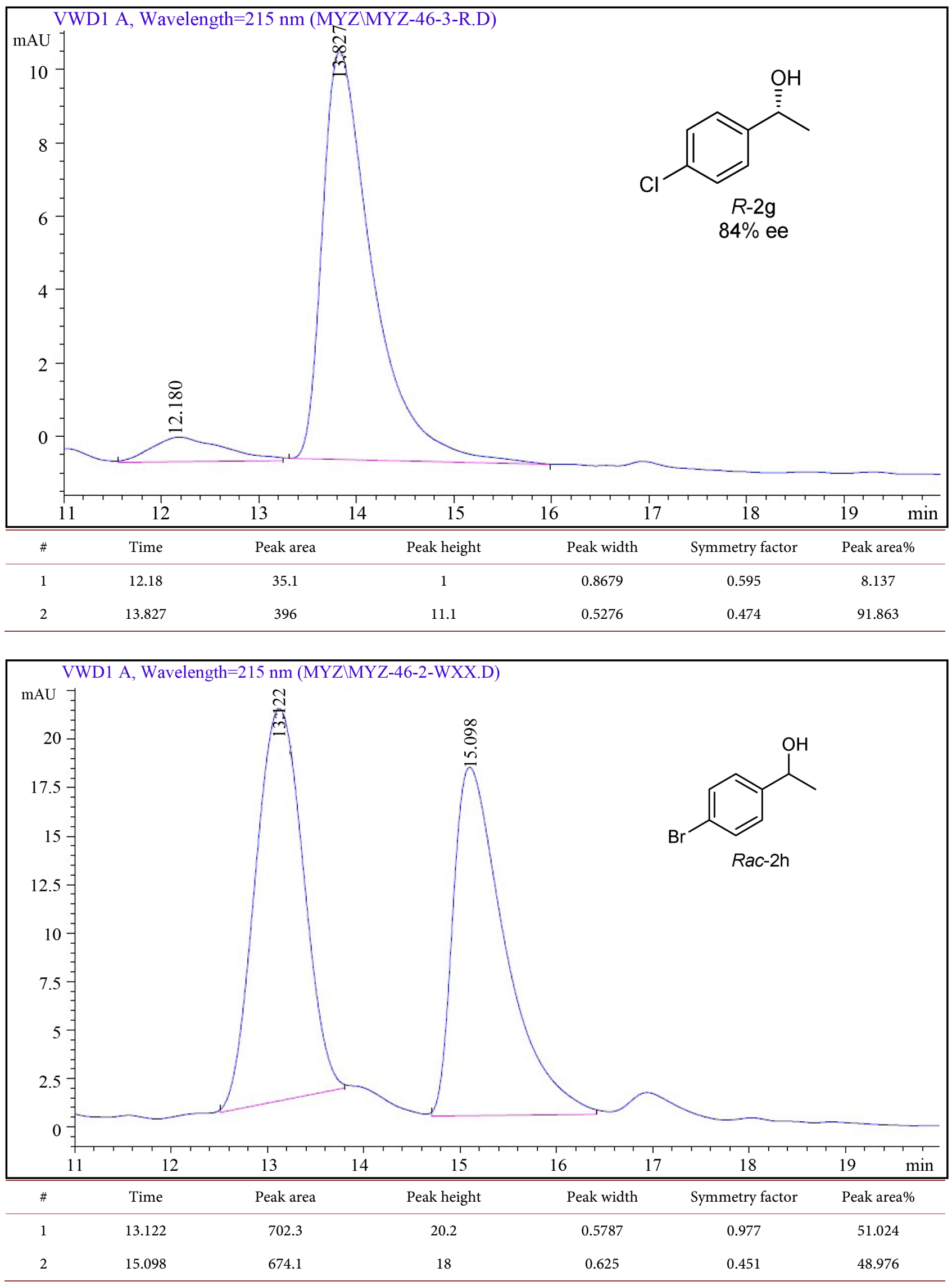

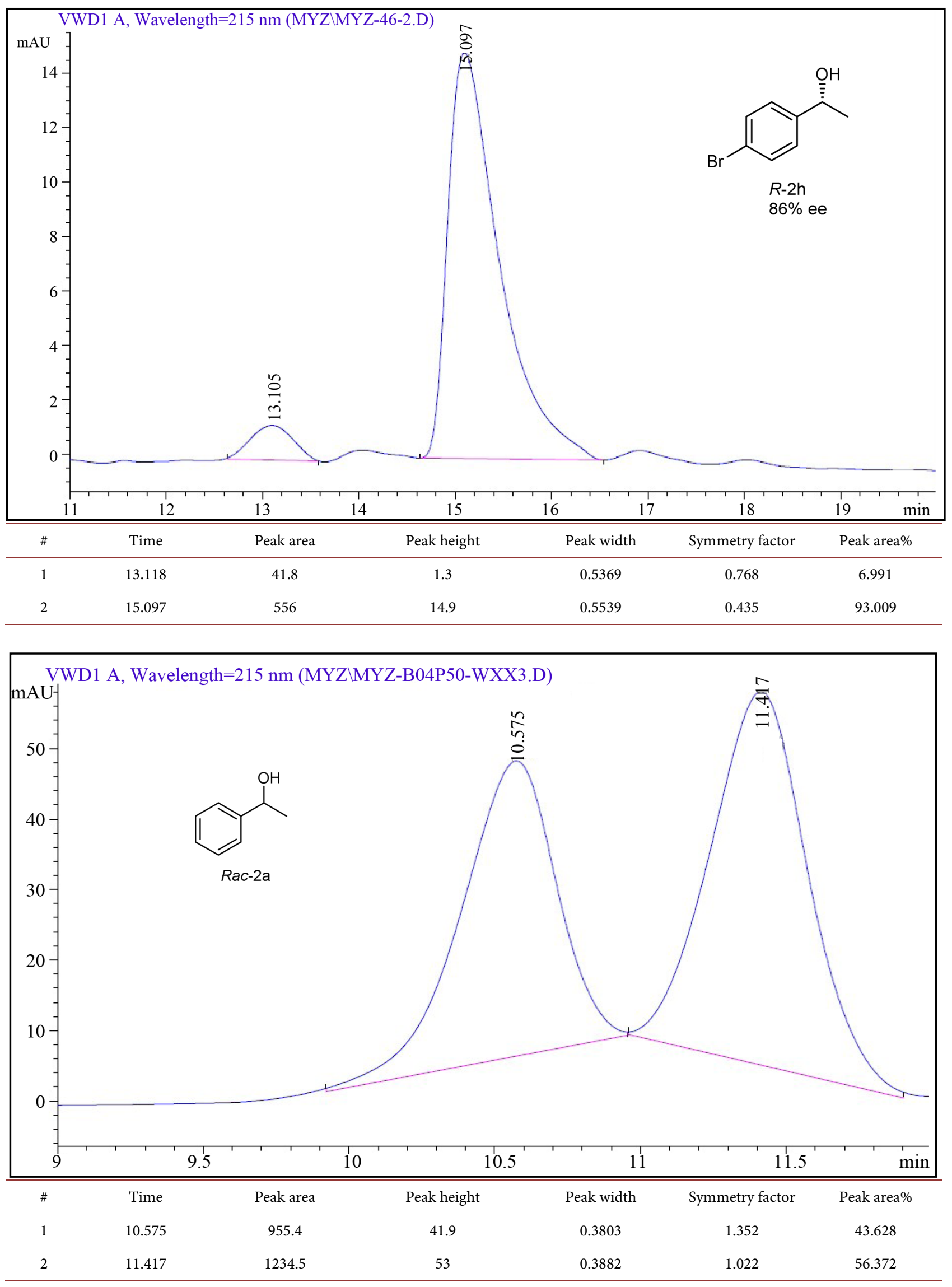

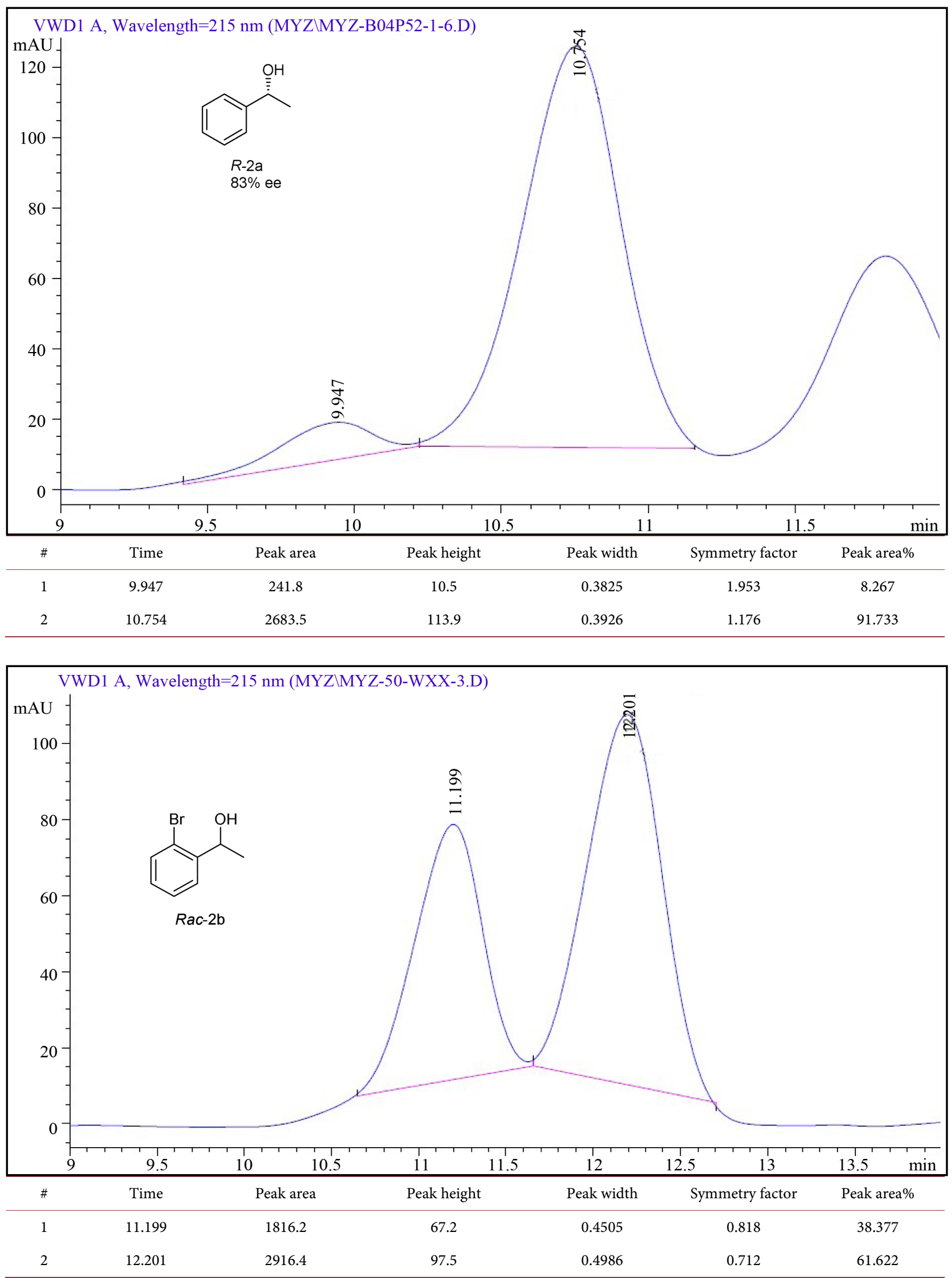

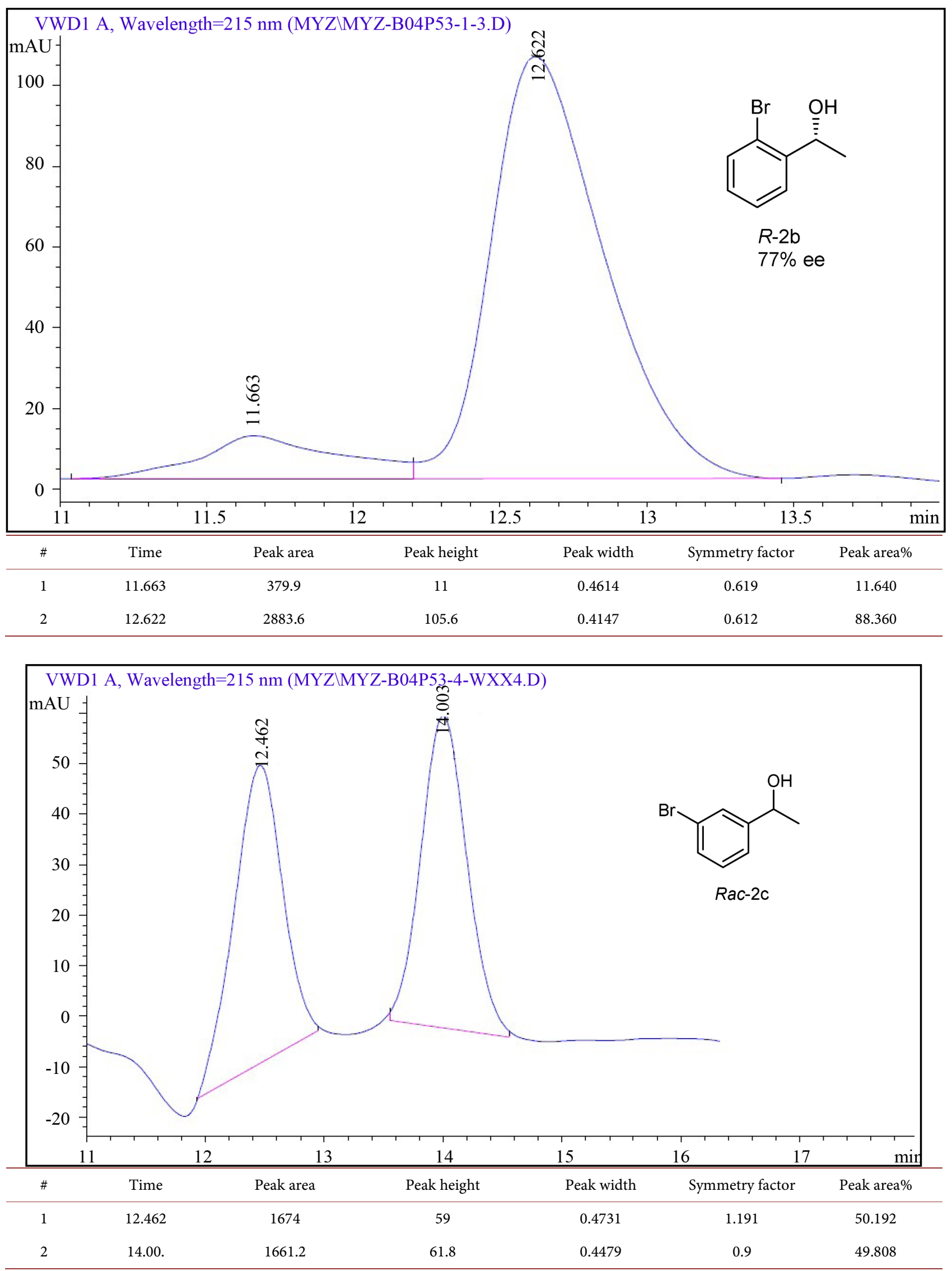

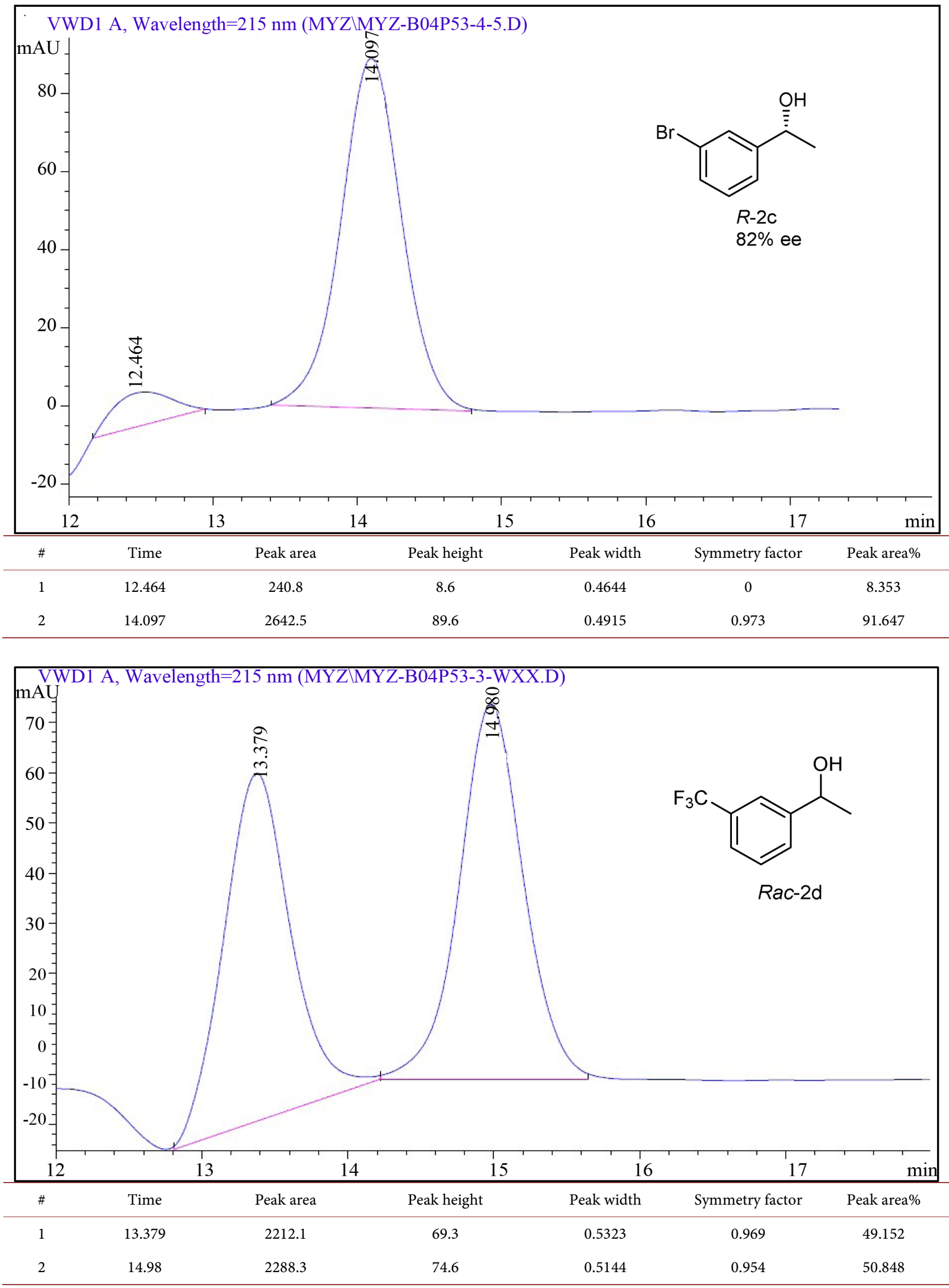

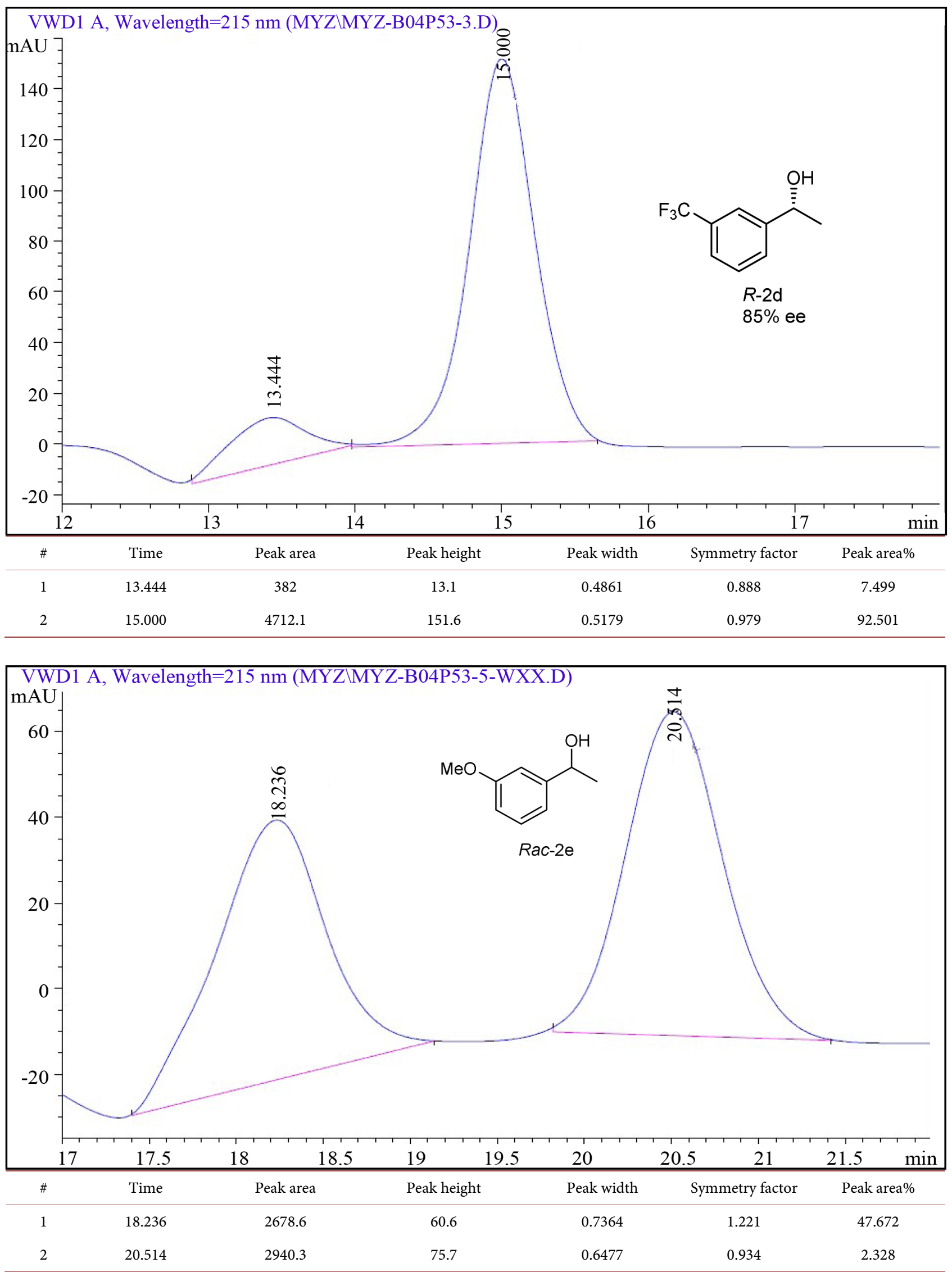

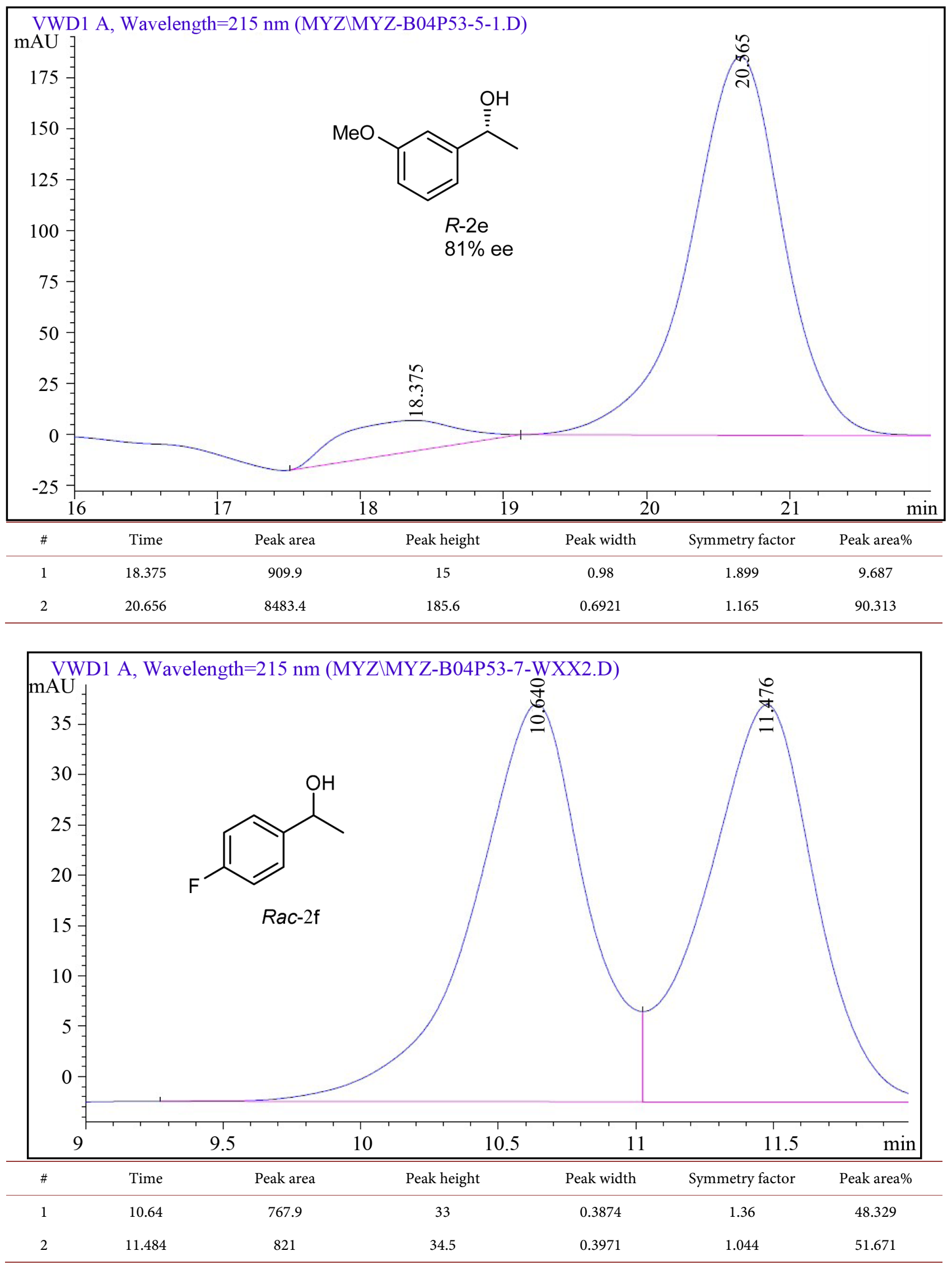

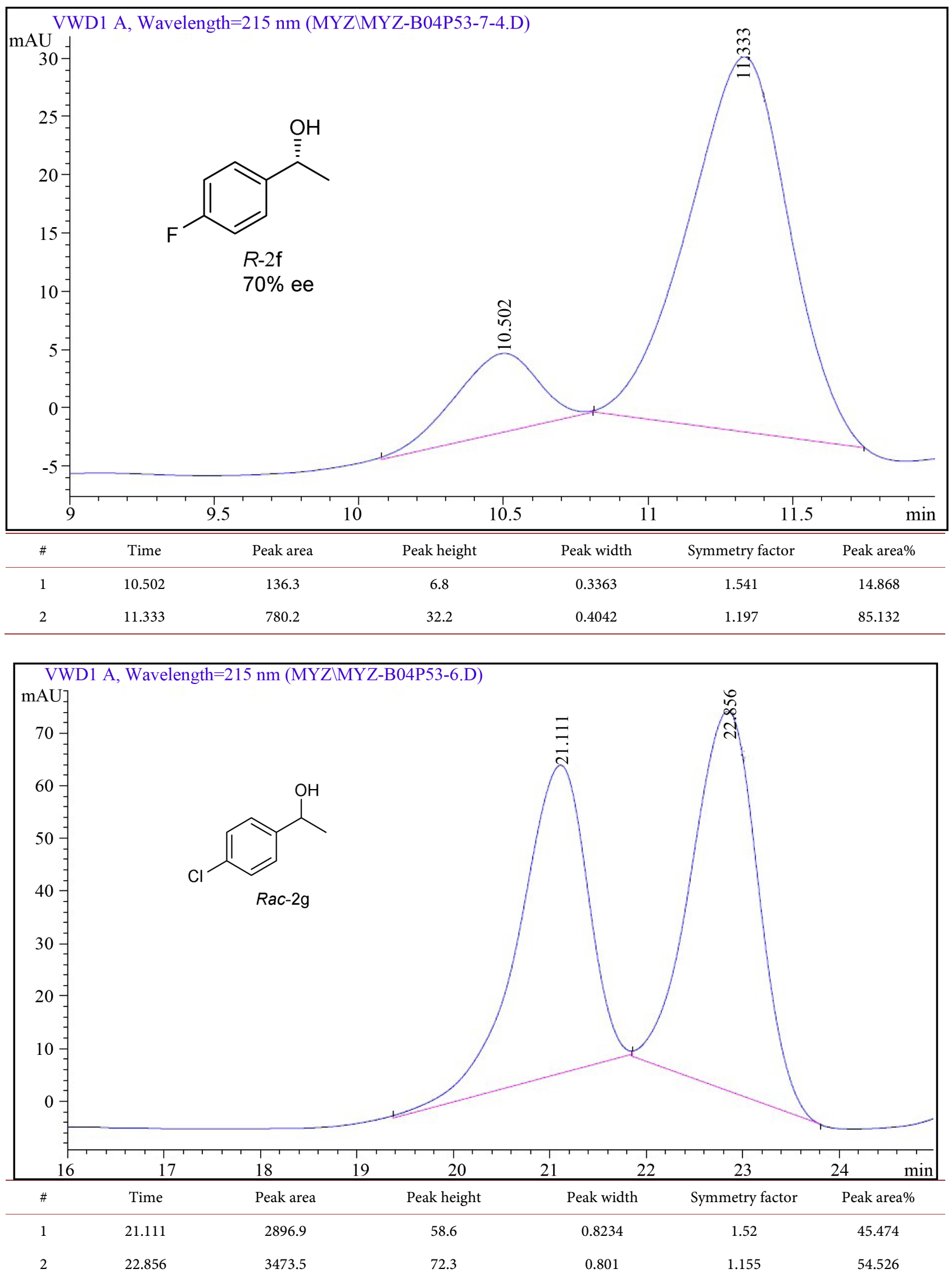

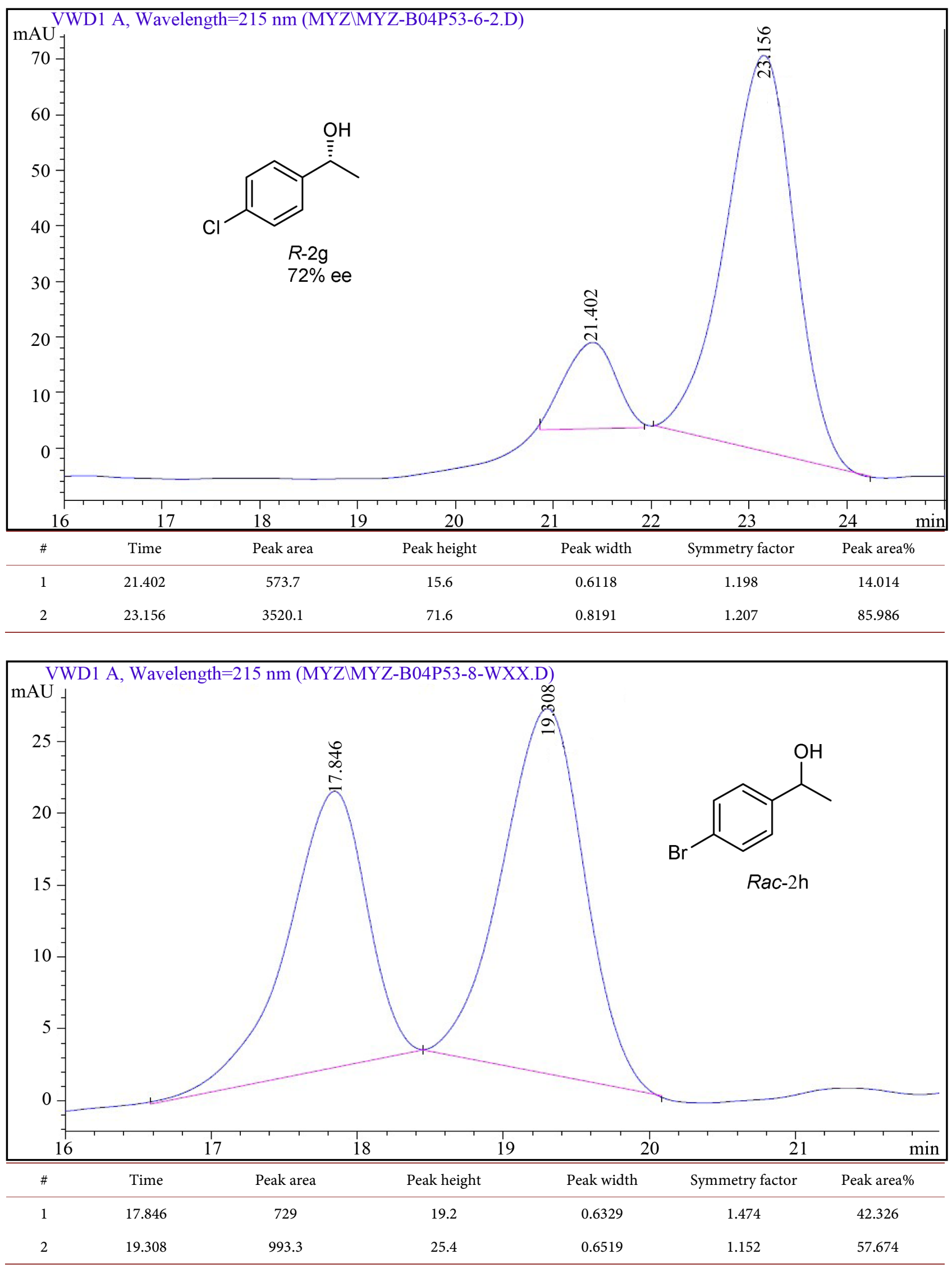


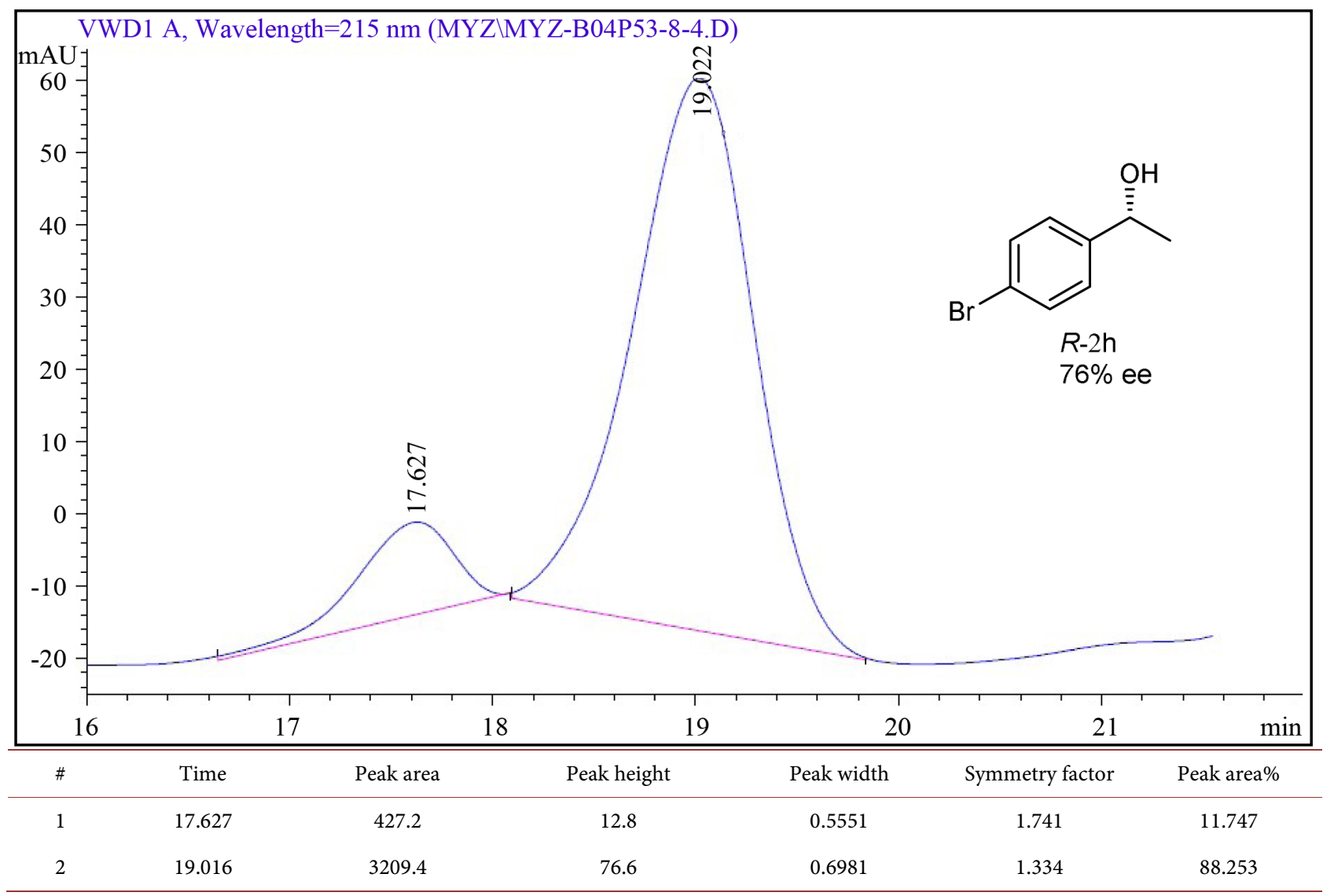

